\title{
Dolomitization of Late Norian carbonate deposits of restricted basin facies in the Keszthely Mts., Transdanubian Range, Hungary
}

\author{
János Haas ${ }^{1} \cdot$ Tamás Budai $^{2} \cdot$ Kinga Hips $^{3}$ - György Czuppon ${ }^{4} \cdot$ Orsolya Győri $^{5}$ · Anikó Horváth ${ }^{6}$ - Gábor Héja ${ }^{2}$
}

Received: 26 March 2021 / Accepted: 15 September 2021 / Published online: 7 November 2021

(c) The Author(s) 2021

\begin{abstract}
In the Transdanubian Range (Hungary), a wide spectrum of Triassic dolomites is known. Mechanism of dolomitization of the platform carbonate successions was subject of a number of studies but the study of dolomitization of basinal carbonates is very limited. Petrographical and isotope-geochemical characteristics of the Upper Triassic dolomitized carbonate deposits, formed in a fault-controlled intraplatform basin, and interpretation of the dolomite-forming processes are presented in the current paper. From the latest Carnian to Middle Norian under semi-arid climatic conditions density-driven flux of seawater derived mesohaline fluids was the dominant mechanism of the near-surface pervasive dolomitization of the thick platform carbonate succession. In the late Middle Norian incipient rifting of the Alpine Tethys led to establishment of an extensional structural regime and onset of the formation of the Kössen Basin. In the study area, above the dolomitized platform carbonate succession, platform-derived carbonate sediments were accumulated in a fault-bounded, semi-restricted sub-basin of the Kössen Basin, whereas talus breccias and debrites were deposited near a basin-bounding master fault. The basin deposits (lower and upper members of the Rezi Dolomite Formation) were subject of early diagenetic dolomitization in shallow burial setting. Enhanced salinity seawater was the dolomitizing fluid; the synsedimentary fracturing may have promoted the fluid flow and thereby the dolomitization. Thick-bedded carbonates (middle member of the Rezi Dolomite Formation) representing a progradational tongue of the ambient platform are intercalated between the basin deposits. The dolomitization of this unit can be explained by the reflux model.
\end{abstract}

Keywords Dolomitization $\cdot$ Reflux $\cdot$ Extensional basin $\cdot$ Triassic $\cdot$ Transdanubian range

\section{Introduction}

Orsolya Győri

gyori.orsi@gmail.com

1 Department of Geology, Institute of Geography and Earth Sciences, Eötvös Loránd University, Pázmány P. sétány 1/c, Budapest 1117, Hungary

2 Mining and Geological Survey of Hungary, Stefánia út 14, Budapest 1143, Hungary

3 Geological, Geophysical and Space Science Research Group, Institute of Geography and Earth Sciences, Eötvös Loránd University, Pázmány Péter sétány 1/c, Budapest 1117, Hungary

4 Research Centre for Astronomy and Earth Sciences, Institute for Geological and Geochemical Research, Eötvös Loránd Research Network (ELKH), Budaörsi út 45, Budapest 1112, Hungary

5 TDE ITS Ltd, Pasaréti út 46, Budapest 1026, Hungary

6 Institute for Nuclear Research, Bem square 18c, Debrecen 4026, Hungary
In spite of more than 200 year research activity of generations of earth scientists, many aspects of the dolomite genesis are still rather enigmatic. There is no doubt, that most dolomites were formed via replacement of calcareous sediments/limestones during diagenesis. However, dolomitization is commonly the result of multiple processes and the reconstruction of the complex history of dolomitization from the end products requires an integrated approach based on results from multidisciplinary methods. Understanding of the syndepositional/penecontemporaneous dolomite forming processes is strongly hampered by the facts that there are only a few examples for dolomite formation in recent/ sub-recent deposits and the laboratory experiments for the reconstruction of dolomite formation under surface conditions have not yielded unambiguous results (McKenzie 1991; Purser et al. 1994; Land 1998; Machel 2004; Gregg et al. 2015). Due to these aspects, the case studies are still 
important tools for understanding the dolomite forming processes, and in many cases, these studies are indispensable for the correlation of the rock bodies and, therefore, the correct lithostratigraphic assignment of many dolomitized carbonate rocks.

The 3-3.5-km-thick Triassic succession of the Transdanubian Range (TR), in NW Hungary, is made up mostly of carbonate rocks and a wide variety of dolomites and partially dolomitized limestones evolved in this domain (Haas et al. 2017). The Keszthely Mountains, forming the westernmost part of TR, consists predominantly of Upper Triassic dolomites representing platform, slope and semi-restricted basin facies. Interpretation of the main controlling factors and reconstruction of dolomite-forming processes of the thick Upper Triassic platform carbonate successions was subject of several studies (Haas et al. 2014a, b, 2015, 2017) but no detailed study of dolomitization of basinal carbonates has been presented so far. That is why the presentation of petrographical and geochemical characteristics of the dolomitized slope and basin dolomites and interpretation of the dolomite-forming processes are placed into the focus of the current paper.

\section{Geological setting}

The study area is in the Keszthely Mts., located at the south-western end of the TR, west Hungary (Fig. 1). The TR belongs to the Transdanubian Range Unit (TRU) that is considered as the eastern continuation of the Upper Austroalpine nappes (Fodor et al. 2003; Tari and Horváth 2010). In the early period of the Alpine plate-tectonic cycle, this unit was located between the South Alpine and Upper Austroalpine realm, as a segment of the Adriatic margin of the Neotethys Ocean (Fig. 2; Haas et al. 1995; Mandl 2000; Gawlick 2000; Csontos and Vörös 2004). Lateral extrusion led to its large-scale eastward displacement during the postcollisional deformation stages of the Alps (Schmid et al. 1989; Ratschbacher et al. 1991; Frisch et al. 1998; Haas

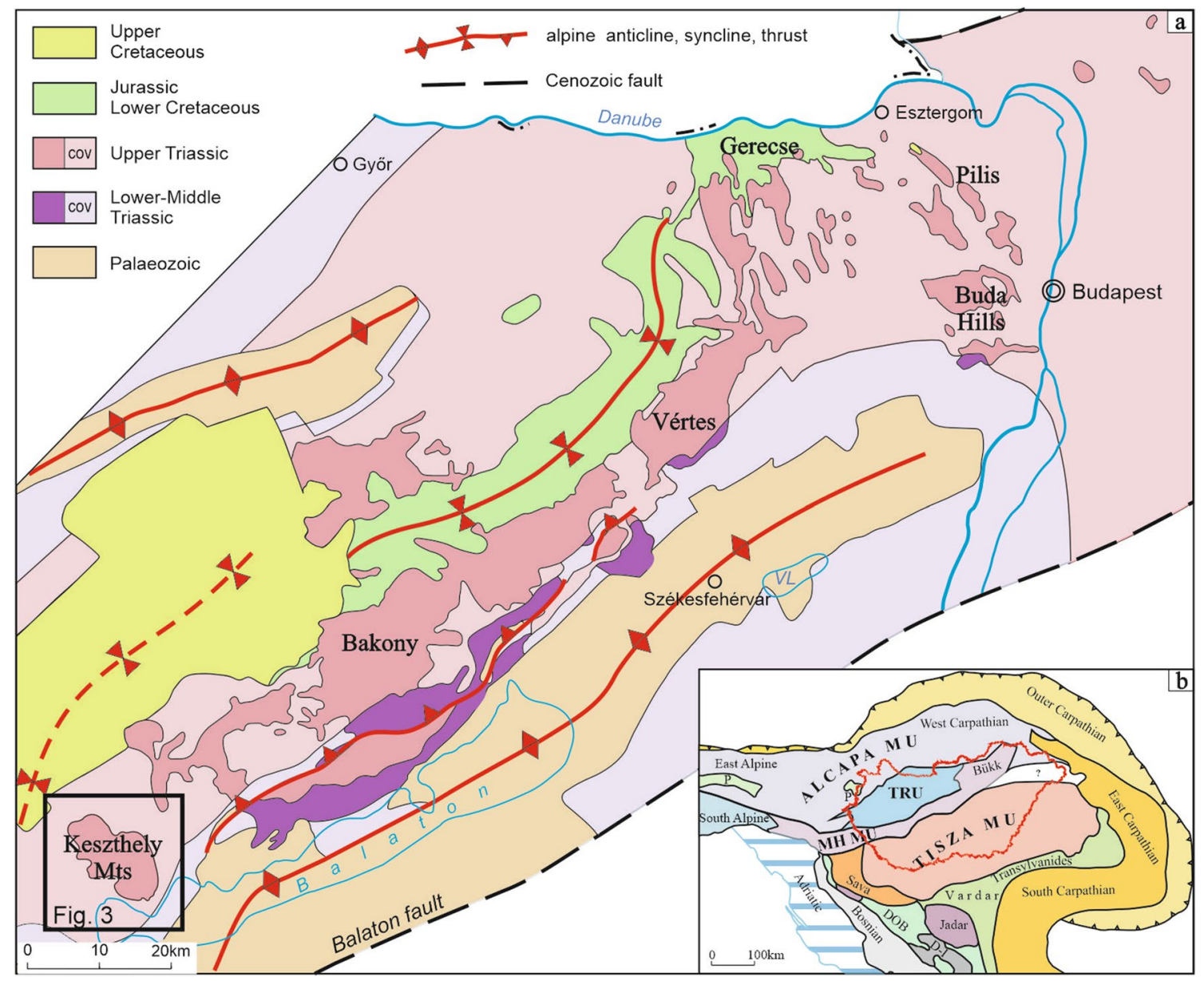

Fig. 1 Simplified pre-Cenozoic geological map a of the Transdanubian Range Unit (TRU); the framed area shows the position of the Keszthely Mts. (modified after Haas and Budai 2004). The inset map b shows the structural setting of the TRU in the Alpine-Carpathic-
Dinaric region (after Haas et al. 2010). Abbreviations: (A) cov covered; (B) $D-I$ Drina-Ivanjica; $D O B$ Dinaridic Ophiolite Belt; $M H$ $M U$ Mid-Hungarian Megaunit; $P$ Penninic Unit 


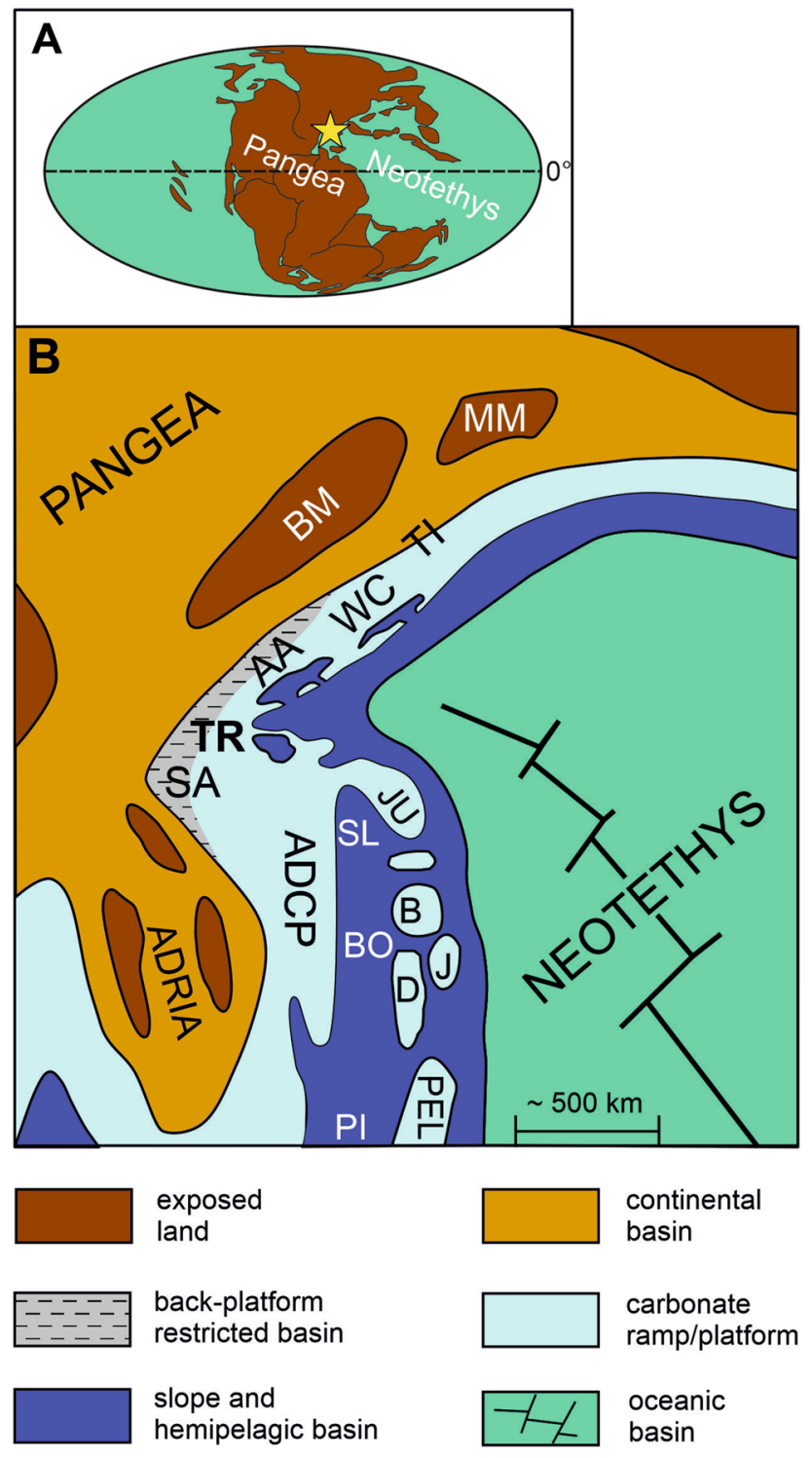

Fig. 2 Position of the study area (yellow star) at the NW termination to the Neotethys Ocean (a) and paleogeographic setting of the TRU in the Late Triassic (modified after Haas et al. 2019) (b). Abbreviations: $A A$ Austroalpine Units; $A D C P$ Adriatic Central Platform; $B$ Bükk Unit; $B M$ Bohemian Massif; $B O$ Bosnian Basin; $D$ Drina-Ivanjica Unit; $J$ Jadar; $J U$ Julian Alps; $M M$ Moesian Massif; Pl; PEL Pelagonian Unit; $S A$ Southern Alps; $S L$ Slovenian Trough; $T l$ Tisza Unit; $W C$ West Carpathian Unit

et al. 2014a, b). The TRU forms an arcuated mega-syncline structure. This mega-syncline is NE-SW directed in the central part of the TRU (Bakony Mts.), whereas it becomes gradually $\mathrm{N}-\mathrm{S}$ trending in the southwestern part of the TRU (Keszthely Mts., Zala Basin; Fodor et al. 2013). The related folds and thrusts came into existence in the mid-Cretaceous. The investigated area belongs to the south-eastern limb of this mega-syncline, and accordingly, the major folds of the Keszthely Mts. are N-S trending (Budai et al. 1999a, b).

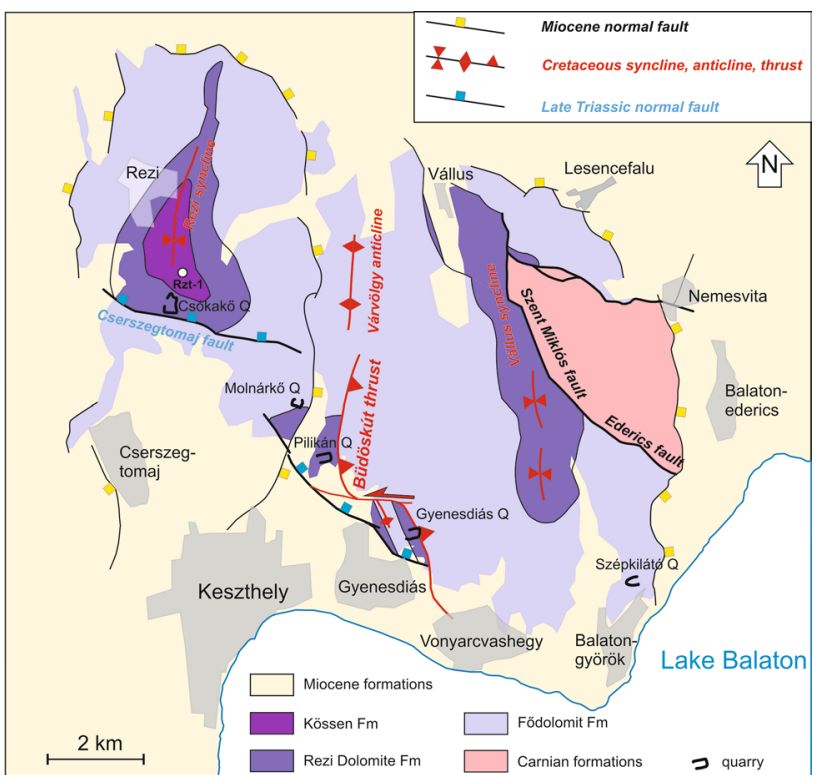

Fig. 3 Simplified pre-Quaternary geological map of the Keszthely Mts. showing the location of the studied sections (after Csillag et al. 1995; Héja et al. 2018)

The Keszthely Mts. are made up mainly by Upper Triassic formations (Figs. 3, 4). A significant fault system divides the mountain into two parts (Budai et al. 1999a, b). The northern segment of this fault system is the $\mathrm{N}-\mathrm{S}$ striking Szent Miklós fault. The southern continuation of this fault is the NW-SE striking Ederics fault (Héja et al. 2018). In the eastern part of this fault system, completely or partially dolomitized or non-dolomitized Carnian platform carbonates (Ederics Limestone) and basinal marl and limestone (Veszprém Marl, Sándorhegy Formation) crop out (Csillag et al. 1995; Budai et al. 1999a, b; Haas et al. 2014a, b). The western side of the mountain comprises mostly Upper Carnian to Lower-Middle Norian platform dolomite (Fődolomit Formation; equivalent with the Hauptdolomit in the Eastern Alps and the Dolomia Principale in the Southern Alps). This internal platform carbonate succession that is made up of cyclic alternation of completely dolomitized subtidal and peritidal beds is widely extended in the TR. East to the Keszthely Mts., in the area of the Bakony Mts., the Fódolomit Formation progresses upward into the Dachstein Limestone through a transitional interval (Fenyőfő Member; upper Middle Norian-lower Upper Norian) that is characterised by entirely dolomitized, partially dolomitized and non-dolomitized segments (Fig. 4, Haas et al. 2015). In the southern part of the Keszthely Mts., the typical cyclic development of the Fódolomit Formation can also be observed, but darker grey, thick-bedded dolomite (dolomitized subtidal facies) occurs directly below the basinal Rezi Dolomite Formation (Budai and Koloszár 1987; Budai et al. 1999b). 
Fig. 4 Upper Triassic stratigraphic chart of the southwestern part of the TRU (South Bakony, Keszthely Mts., Zala Basin) (modified after Haas and Budai 1995; Haas et al. 2014a, b). F Mb Fenyőfő Member; $K L$ Kardosrét Limestone; $S$ Sándorhegy Fm; $S D$ Sédvölgy Dolomite. Drilled cores: Rezi Rzt-1 Zalaszentlászló Zl-1

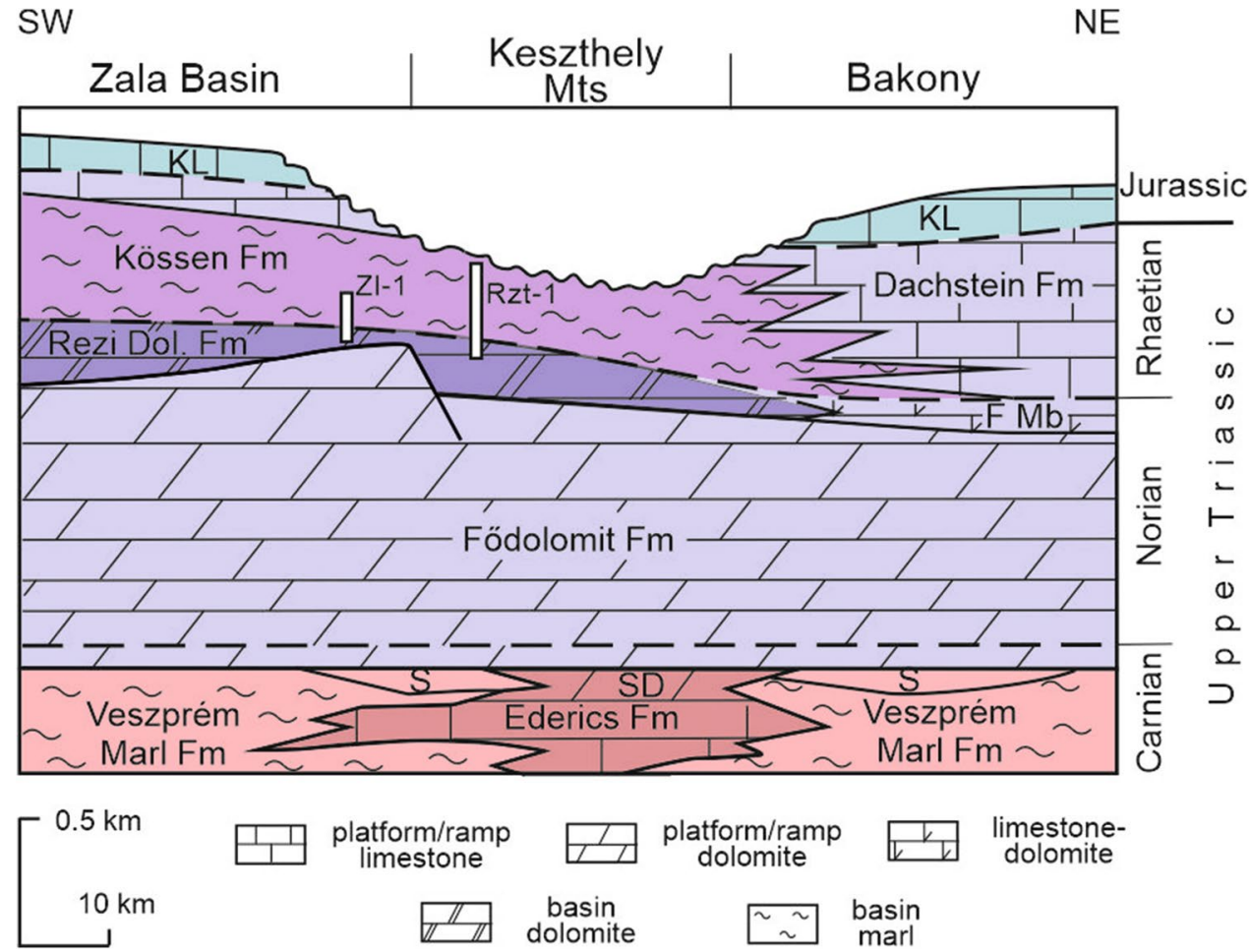

From the end of Middle Norian fault-bounded basins began to develop, where the Rezi Dolomite and then the Kössen Marl were formed during the Late Norian and Rhaetian. These formations are preserved mostly in the central part of Cretaceous synclines of the Keszthely Mts.

The Upper Norian Rezi Dolomite consists of grey, thinbedded and laminated, locally cherty dolomite of semirestricted basinal facies (Fig. 5). The rocks are relatively rich in organic matter. Based on measurements of cores from Rezi Rzt-1 well and Zalaszentlászló Zl-1 well (Figs. 3, 4) representing the uppermost part of the Rezi Dolomite, the TOC ranges from 0.7 to $6.8 \%$. The organic matter is predominantly of marine origin (unicellular planktonic algae) and immature $\left(R_{\mathrm{o}} 0.32-0.34 \%\right.$; Vető et al. 2000; Hetényi et al. 2002). Ostracodes occur in some layers in rock-forming quantity (Budai et al. 1999b). The presence of a monospecific conodont-assemblage (Metapolygnathus slovakensis) was also reported in the lower member (Budai and Kovács 1986). According to a recent comparative study (Du et al. 2021) the time range of this species (its present-day name Mockina slovakensis) is latest Alaunian to late Sevatian. Thick-bedded to massive dolomite (middle member), rich in bioclasts (dasycladalean algae, gastropods and bivalves) is intercalated into the basinal succession which were interpreted as a dolomitized progradation tongue of the neighbouring carbonate platform (Csillag et al. 1995; Budai et al. 1999b). The thin-bedded, laminated dolomite in the upper part of the Rezi Dolomite is overlain by Upper Norian to Rhaetian dark grey to black marl of the Kössen Formation
(Fig. 5). A 10-m-thick transitional interval, made up of alternation of dolomite, dolomarl and limestone, occurs in the basal part of the Kössen Formation (Haas 1993).

Due to multistage denudation from the mid-Cretaceous onward, Mesozoic formations younger than Rhaetian are not known in the area of the Keszthely Mts. However, the younger Mesozoic to Cenozoic formations have been preserved in other parts of the TR, north-east to the Keszthely Mts., allowing the reconstruction of the evolutionary history for the missing parts (Vörös and Galácz 1998; Haas et al. 1985; Horváth and Cloething 1996; Budai et al. 1999b; Magyar et al. 1999; Haas 2012).

\section{Materials and methods}

The basic concept of the sampling was to represent the lithofacies types of the Upper Triassic succession from the upper part of the Fôdolomit Formation through the transitional interval and the Rezi Dolomite Formation to the basal part of the Kössen Formation. A series of abandoned quarries along the western belt of the Keszthely Mts. (Fig. 3) provided a good opportunity for sampling of suitable sections from the upper part of the Fódolomit Formation up to the middle member of the Rezi Dolomite. Since no suitable surface exposures were available for the upper part of the Rezi Dolomite, well Rzt-1 (Figs. 3, 4) was sampled for representation of this member. 


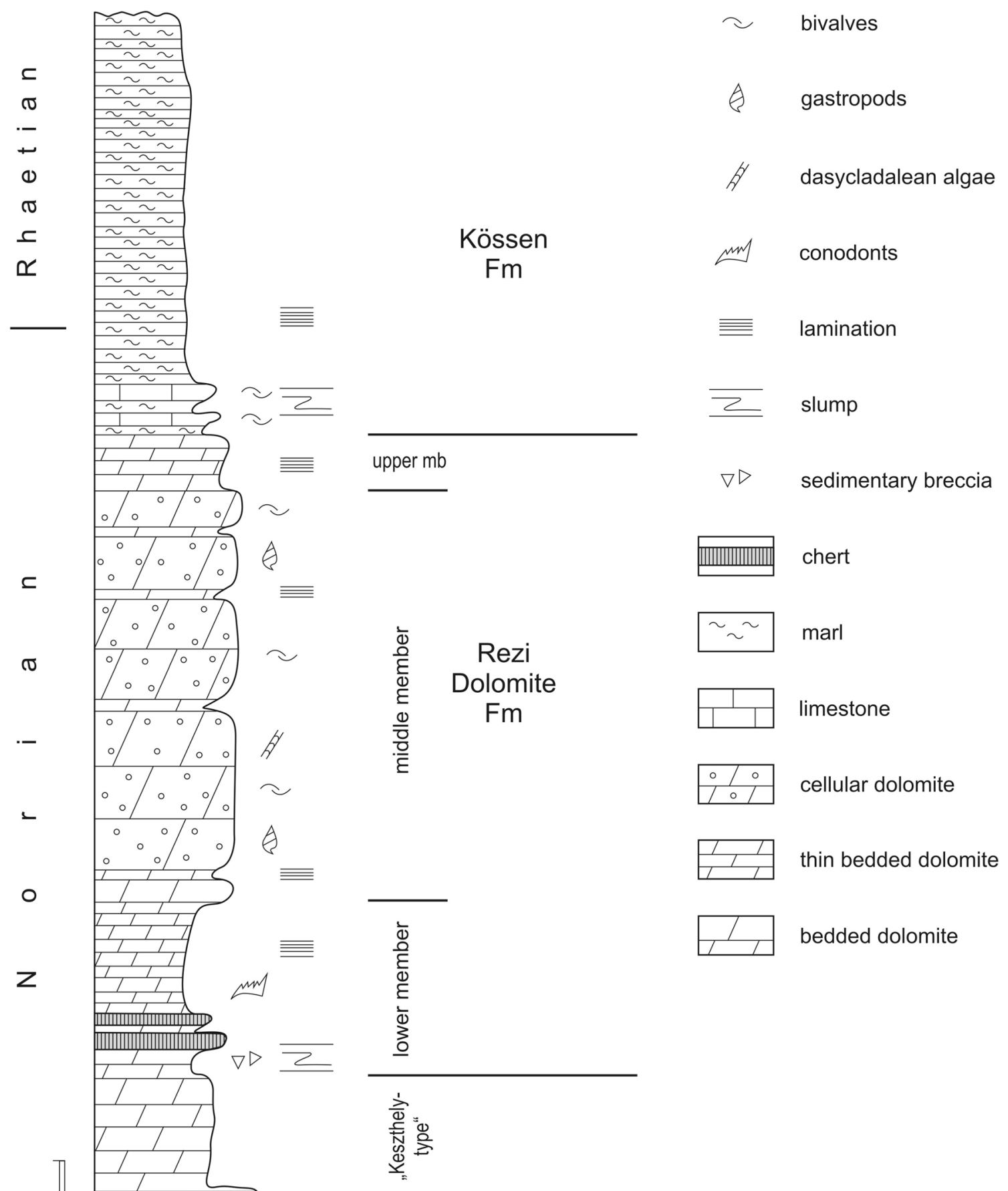

\section{Fődolomit}

$\mathrm{Fm}$

Fig. 5 Stratigraphic column of the Upper Norian-Rhaetian formations of the Keszthely Mts. (Budai et al. 1999a)

From the above outcrops and cores, 45 samples were taken, and 58 thin sections were made for petrographic studies. The thin sections were stained by Alizarin red-S and potassium ferricyanide to determine the carbonate phases in the samples (Dickson 1966). For description of the dolomite texture the classification proposed by Sibley and Gregg (1987) was applied. Folk's classification (1962) was applied for description of the crystal size.

Stable carbon and oxygen isotope analyses of the dolomite samples (in total 86 samples, Table 1, Online Resource) 
were carried out using the continuous flow technique (Spötl and Vennemann 2003), and dolomite reaction conditions and fractionation factors described by Rosenbaum and Sheppard (1986). The samples for stable isotope analyses were prepared using an electric microdrill with a bit diameter of $0.6 \mathrm{~mm}$. The obtained powders $(150-200 \mu \mathrm{g})$ were dissolved by carbonate-orthophosphoric acid reaction at $72{ }^{\circ} \mathrm{C}$ (Spötl and Vennemann 2003). The ${ }^{13} \mathrm{C} /{ }^{12} \mathrm{C}$ and ${ }^{18} \mathrm{O} /{ }^{16} \mathrm{O}$ ratios were determined in $\mathrm{CO}_{2}$ gases liberated by phosphoric acid using an automated GASBENCH II sample preparation bench attached to a Thermo Finnigan Delta Plus XP Isotope Ratio Mass Spectrometer (Thermo Fisher Scientific, Bath, UK) at the Institute for Geological and Geochemical Research, Research Centre for Astronomy and Earth Sciences, (IGGR, RCAES) Budapest, Hungary. Standardization was conducted using laboratory standards calibrated against the NBS 18 and NBS 19 standards. During the measurement of the dolomite samples, a laboratory dolomite standard (DST; calibrated to NBS-19) was used. All samples were measured at least in duplicate, and the mean values are in the traditional $\delta$ notation in parts per thousand (\%o) relative to Vienna Pee Dee Belemnite (VPDB). Reproducibility is better than \pm 0.1 $\%$ for $\delta^{13} \mathrm{C}$ and $\pm 0.1 \%$ or $\delta^{18} \mathrm{O}$.

The Total Organic Carbon (TOC) percentage of the dolomite samples (5 samples, Table 2, Online Resource) was determined at IGGR. The dolomite samples were treated by hydrochloric acid (10\%) and the remaining fraction (between 0.3 and $2.5 \mathrm{mg}$ ) was wrapped in a tin capsule. Triple aliquots of 0.3-2.5 mg samples were weighed and wrapped into $\mathrm{Sn}$ capsules (IVA Analysentechnik e.K. Meerbusch, Germany) for the measurements of $\mathrm{C}$ elemental percentage (Karlik et al. 2018). The element specific peak area was detected by the internal TCD detector of the Flash 2000 Elemental Analyzer (Thermo Scientific, Rhodano, Italy). The element percentage was calculated according to Hedges and Stern (1984) as

$C \%=\frac{\left(A_{\mathrm{spl}}^{\mathrm{C}}-A_{\mathrm{blk}}^{\mathrm{C}}\right) / K}{W_{\mathrm{spl}}}$,

where $A_{\mathrm{spl}}$ and $A_{\mathrm{blk}}$ stand for the peak area of the sample and the blank, respectively; and $K$ is the average $K$-Factor determined by a 6-point calibration curve fitted with the $K$-factor function in the mass range of $0.3-2.5 \mathrm{mg}$. Applied standard material was $N$-phenylacetamide (Acetanilide, Thermo Scientific, Cambridge, UK). Reproducibility of the analyses is estimated by the standard deviation of the Acetanilide standards $(n=6)$ which was $0.5 \%$ for $\mathrm{C} \%$, respectively.

The carbon isotope composition of Total Organic Carbon $\left(\delta^{13} \mathrm{C}_{\mathrm{TOC}}\right)$ was measured by a Thermo Scientific Delta $\mathrm{V}$ Advantage Isotope Ratio Mass Spectrometer in continuous flow mode, coupled with a Flash 2000 Elemental Analyzer and a ConFlo III interface at IGGR. The dolomite samples were treated by hydrochloric acid (10\%) and the remained fraction (between 0.3 and $2.5 \mathrm{mg}$ ) was wrapped in a tin Sn capsule and fed to the Elemental Analyzer; the resulting $\mathrm{CO}_{2}$ gas was analysed by Mass Spectrometer following the method presented by Karlik et al. (2018). The isotopic compositions were calibrated against repeated analyses of two international standards (IAEA-CH6, $-10.449 \%$, and IAEA-CH7, $-32.151 \%$ ). The long-term reproducibility is estimated to be better than $0.1 \%$.

Strontium isotope composition of dolomites ( 7 samples, Table 3, Online Resource) was determined at the Institute for Nuclear Research (ICER) in Debrecen. All sample preparation was done in a Class 1000 cleanroom. For strontium isotope analyses, $10-15 \mathrm{mg}$ samples were drilled using an electric microdrill with a bit diameter of $0.6 \mathrm{~mm}$. Then, ultrapure water (UPW; Merck, $18 \mathrm{M} \Omega \cdot \mathrm{cm}$ ) and doubly distilled $14 \mathrm{~mol}^{-1}$ nitric acid were used for sample digestion, resin cleaning and elutions. The powdered dolomite samples were dissolved in $1 \mathrm{M}$ acetic acid (Rieder et al. 2019) solution in PTFE vessels. Crown ether-based Sr-Spec Resin (100-150 mm particle size) (Triskem International, France) was pre-cleaned prior to use with $8 \mathrm{M} \mathrm{HNO}_{3}$ and UPW. Sr was isolated from the matrix components and $\mathrm{Rb}$ (isobaric overlap ${ }^{87} \mathrm{Sr}^{+}$and ${ }^{87} \mathrm{Rb}^{+}$). After the separation, the solution was evaporated to dryness and $1 \mathrm{ml}$ of $14 \mathrm{~mol}^{-1}$ nitric acid was added and evaporated again. The residue was taken up in $4 \mathrm{ml} 3 \% \mathrm{HNO}_{3}$ solution. Standard solutions were prepared from the $\mathrm{NBS} 87 \mathrm{SrCO}_{3}$ (National Institute of Standards and Technology). Strontium isotope ratios were measured using a Neptune Plus MC-ICP-MS (Thermo Fisher Scientific) equipped with an Aridus-3 (CETAC) desolvation system. The ${ }^{87} \mathrm{Sr} /{ }^{86} \mathrm{Sr}$ ratio was corrected for instrumental mass discrimination using $\left({ }^{88} \mathrm{Sr} /{ }^{86} \mathrm{Sr}\right)=8.375209$, as well applying an interference correction for ${ }^{87} \mathrm{Rb}^{+}$and ${ }^{86} \mathrm{Kr}^{+}$. Reproducibility of the standard NBS987 during analysis of samples was $0.710257 \pm 0.000018(1 \sigma, n=6)$. All values have been normalised to the accepted value of 0.710240 for NBS987.

\section{Results}

\section{Lithological and petrographic characteristics}

The typical cyclic peritidal development of the Fődolomit Formation is exposed in small quarries in the southern part of the Keszthely Mts. near Balatongyörök. From among them, the Szépkilátó Quarry was studied (Fig. 3). The exposed succession is made up of cyclic alternation of $2-5$-m-thick beds of beige or light (rarely dark) grey finely crystalline dolomite and 0.1-1.0-m-thick fenestral laminated microbial boundstone (stromatolite) layers (Fig. 6a, b). The cycles exhibit the characteristics of Lofer cycles (Fischer 

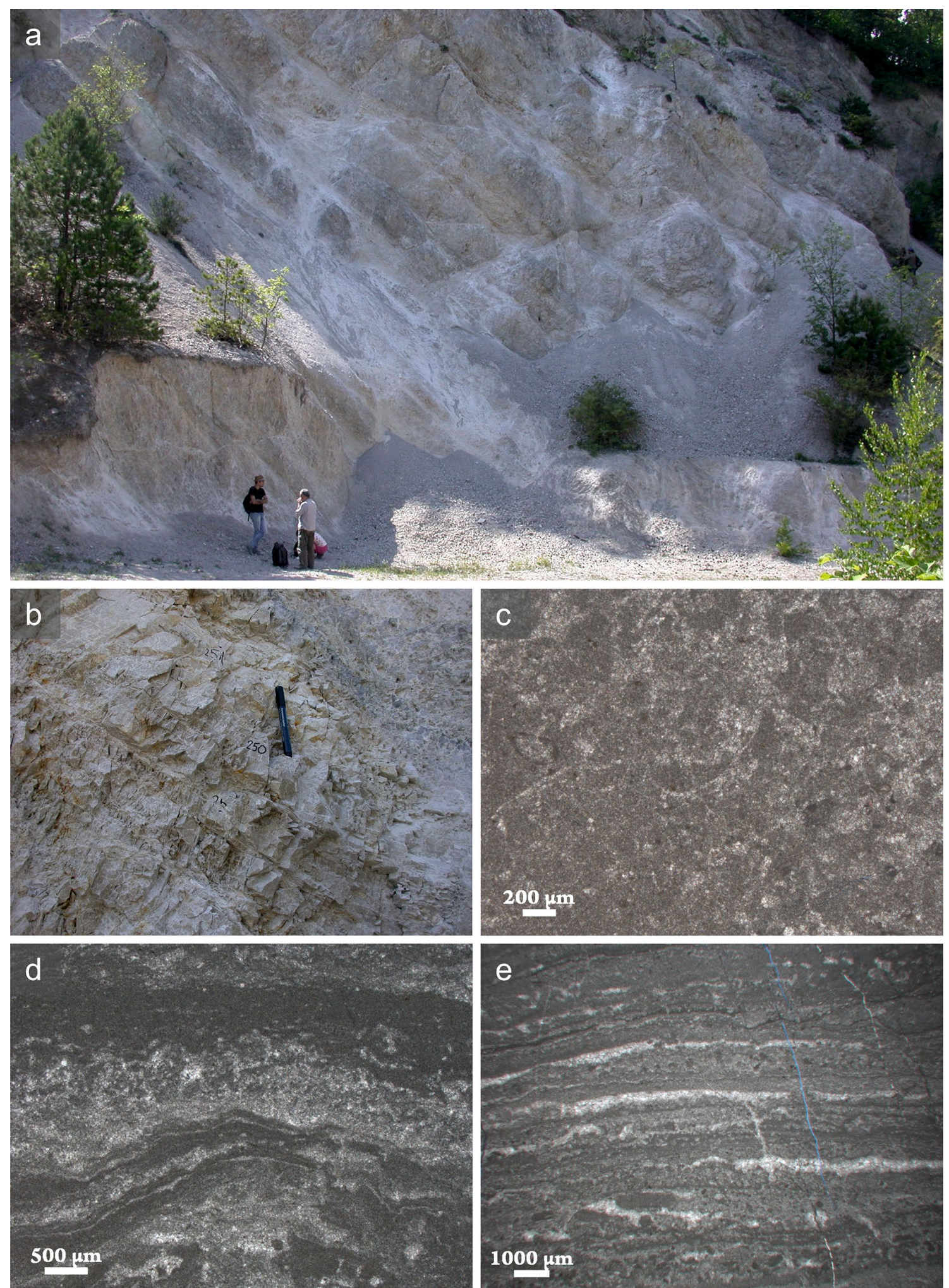

Fig. 6 Depositional structures and petrographic features of the Fődolomit Formation in the Szépkilátó Quarry. a Thick finely crystalline dolomite beds alternate with thinner stromatolite beds. b Thin, parallel laminated stromatolite interbeds between two thick beds. c Very finely to finely crystalline dolomite with poorly preserved fab-

ric; thin-shelled ostracodes are recognisable (sample 249). d Wellpreserved microbial structures in a stomatolite bed (sample 251). f Well-preserved microbial fabric; peloidal dolo-microsparite with bedding parallel sheet cracks and fenestral pores, which are filled by finely crystalline dolomite cement 
1964; Haas 1991). The stromatolite layers correspond with the peritidal $\mathrm{B}$ member, and the thick beds with the subtidal $\mathrm{C}$ member of the Lofer cycle.

The $\mathrm{C}$ members consist of replacive, fabric-destructive, finely to medium crystalline $(20-80 \mu \mathrm{m})$, planar-s dolomite with solid inclusion-rich cores and limpid rims. However, poorly to moderately preserved sedimentary texture (bioclastic, lithoclastic, peloidal wackestone) was also observed (Fig. 6c). The sedimentary structure of the B members is perfectly preserved. Slightly undulating very finely crystalline microbial boundstone laminae with fenestral pores are visible (Fig. 6d,e). The fenestral pores are filled by finely and medium crystalline dolomite (dolomitized calcite cement), and coarsely crystalline dolomite cement (Online Resource $1)$. The finely crystalline replacive dolomite is non-luminescent (Fig. 7a,b). The fenestral pores (many of them are enlarged by dissolution) are occluded or partially filled by a non-luminescent blocky cement phase. The second generation of cement has rhombohedral form and exhibits dull red CL zonation (Fig. 7a,b). This latter cement phase also appears in fracture pores that interconnect the larger fenestral pores.

The medium to dark grey, thick-bedded dolomite unit (upper part of the Födolomit Fm), that will be referred in this paper as "Keszthely-type dolomite" was studied in the middle yard of the Gyenesdiás Quarry (Figs. 3, 8). The exposed succession is made up of alternating thick and very thick $(1.0-1.5 \mathrm{~m})$, medium $(20-40 \mathrm{~cm})$ and thin $(8-15 \mathrm{~cm})$ beds (Fig. 9a, b). In the lower part of the investigated interval, relatively well preserved peloidal, intraclastic wackestone sedimentary fabric was observed. Favreina-type faecal pellets were recognised in the finely crystalline dolomite matrix (Fig. 9c). The millimetre-sized grains, exhibiting various fabric (mudstone, bioclastic, peloidal wackestone and peloidal packstone) are probably intraclasts. Aphanocrystalline and very finely to finely crystalline dolomite laminae alternate in the overlying thin bed, where synsedimentary microfaults and brecciation were encountered (Fig. 9d). Above it, brecciated fabric was observed in a thick bed. The millimetre-to-centimetre-sized, unrounded clasts consist of very finely crystalline dolomite, whereas the matrix is finely to medium crystalline (Fig. 9e).

The lower member of the Rezi Dolomite is exposed in the western yard of the Gyenesdiás Quarry (Fig. 8). The succession is made up of alternating thick-bedded $(0.5-1.0 \mathrm{~m})$ medium grey and thin-bedded $(2-15 \mathrm{~cm})$ and laminated dark grey dolomite (Fig. 10a). The dolomite is unimodal, finely crystalline (10-50 $\mu \mathrm{m})$, planar-s; the sedimentary fabric was completely destroyed (Online Resource 1; Fig. 10b). The fractures are occluded by medium to coarsely crystalline (50-500 $\mu \mathrm{m})$ dolomite cement (Fig. 10c).

The lower member of the Rezi Dolomite succession is exposed also in the eastern yard of the Gyenesdiás Quarry (Fig. 8). The studied section comprises medium to thickbedded (bed thickness is $10-40 \mathrm{~cm}$ ) brownish grey and dark grey dolomite. Within the beds, parallel lamination is common (Fig. 11a). Slump folds were encountered in some beds and lateral outpinching of some layers was also observed.
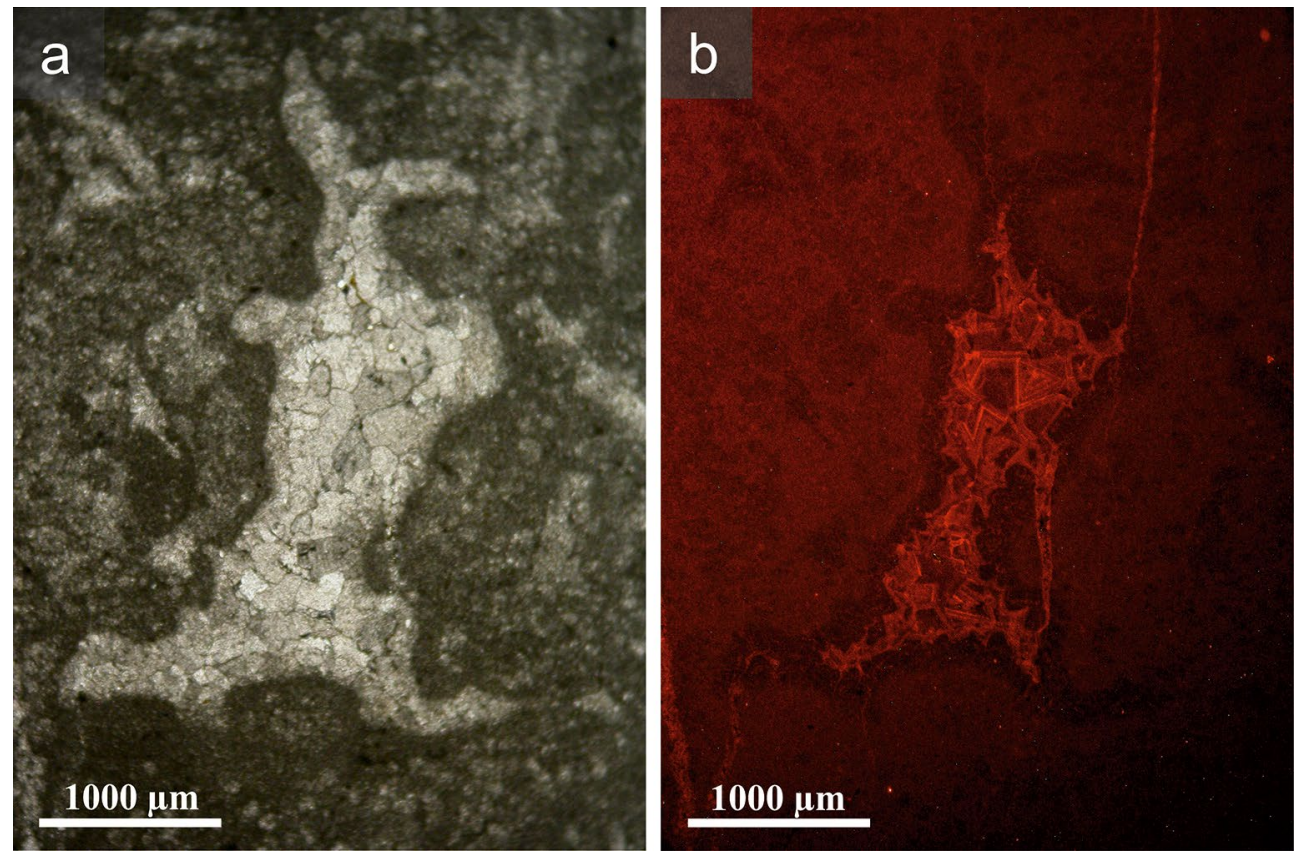

Fig. 7 Photomicrograph (a) and cathode-luminescence image (b) of a fenestral pore. The pore is lined by a non-luminescent blocky cement phase, whereas its central part is occluded by coarse rhombohedral crystals exhibiting dull red CL zonation (sample 250) 


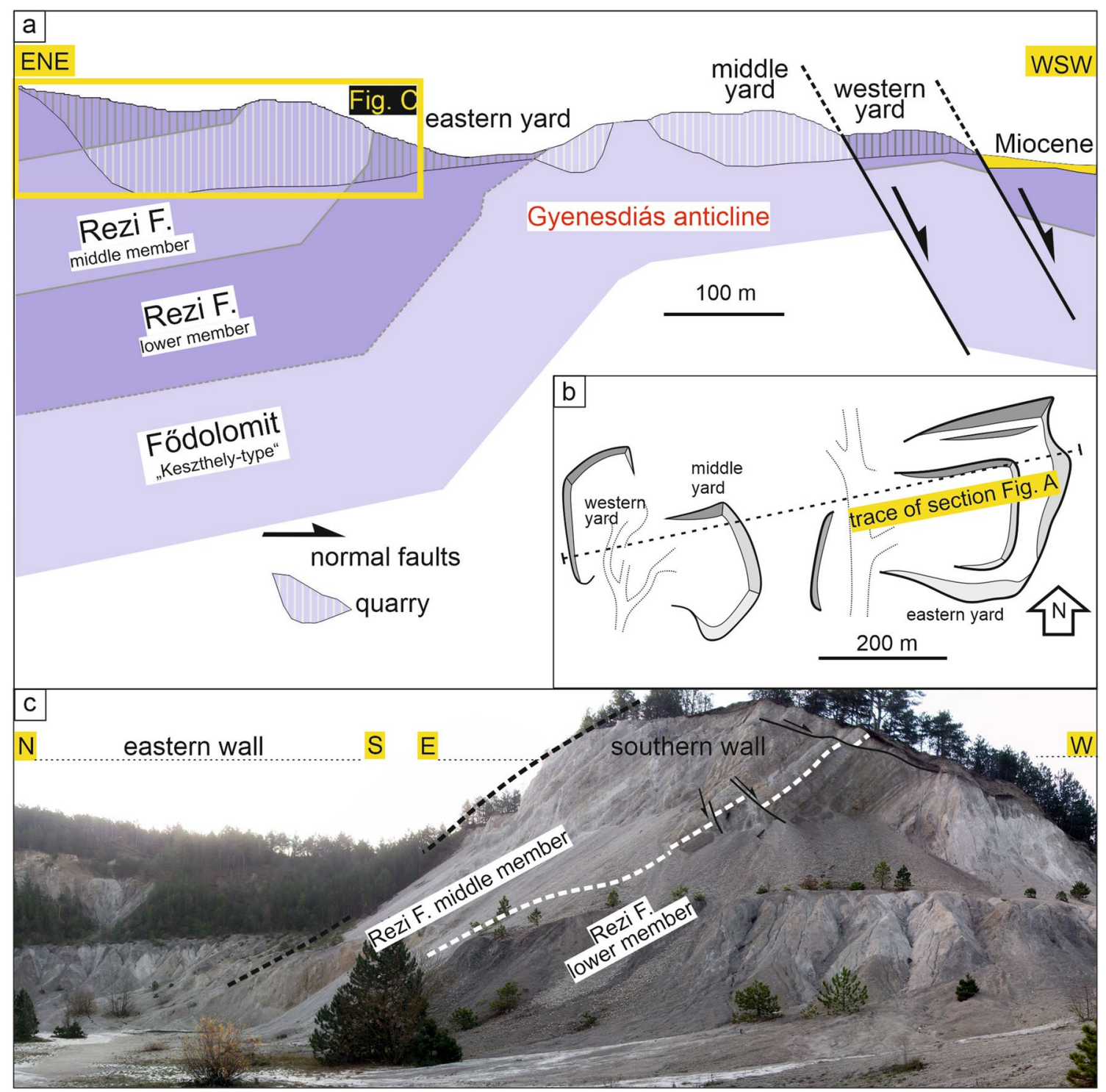

Fig. 8 a Geological cross section of the Gyenesdiás anticline in the southern prolongation of the Várvölgy anticline (see Fig. 3). b Position of the Gyenesdiás quarry yards; $\mathbf{c}$ panoramic view on the eastern yard

Well-preserved sedimentary fabric, bioclastic wackestone/ packstone was found in some layers (Online Resource 1). In the very finely crystalline dolomite ghosts of ostracods and fragments of thin-shelled bivalves are common; ostracod coquina laminae occur, locally (Fig. 11b). Finely crystalline dolomite of poorly preserved sedimentary fabric with ghosts of bioclasts and peloids (Fig. 11c), furthermore, completely fabric-destructive finely crystalline $(50-150 \mu \mathrm{m})$ dolomite was also found in other beds. This thin-to-medium-bedded interval is overlain by thick-bedded to massive dolomite that forms a progradational tongue containing platform-derived components (middle member of the Rezi Dolomite).

The lower member of the Rezi Dolomite is exposed also in the Pilikán Quarry (Fig. 3). The dolomite is very thick, thick- and medium-bedded, beige, light grey and dark grey, and finely crystalline. Intertonguing into the bedded succession, metre-sized, matrix-supported breccia bodies occur. In certain parts of the quarry, the rocks are fractured, and the pore network is occluded by dolomite cement. In the lower part of the studied section 3-1.5-m-thick beds occur. These beds consist of aphanocrystalline to finely crystalline (max. $50 \mu \mathrm{m}$ ), fabric-destructive dolomite (Online Resource 1 ). They are cut through by thin fractures with medium to coarsely crystalline (max. $800 \mu \mathrm{m}$ ) dolomite cement.

Above an uneven surface, the thick-bedded interval is overlain by a peculiar rock body that is made up of finely crystalline dolomite containing 1-10-cm-sized clasts and irregular mottles (Fig. 12a). The matrix is light beige, 

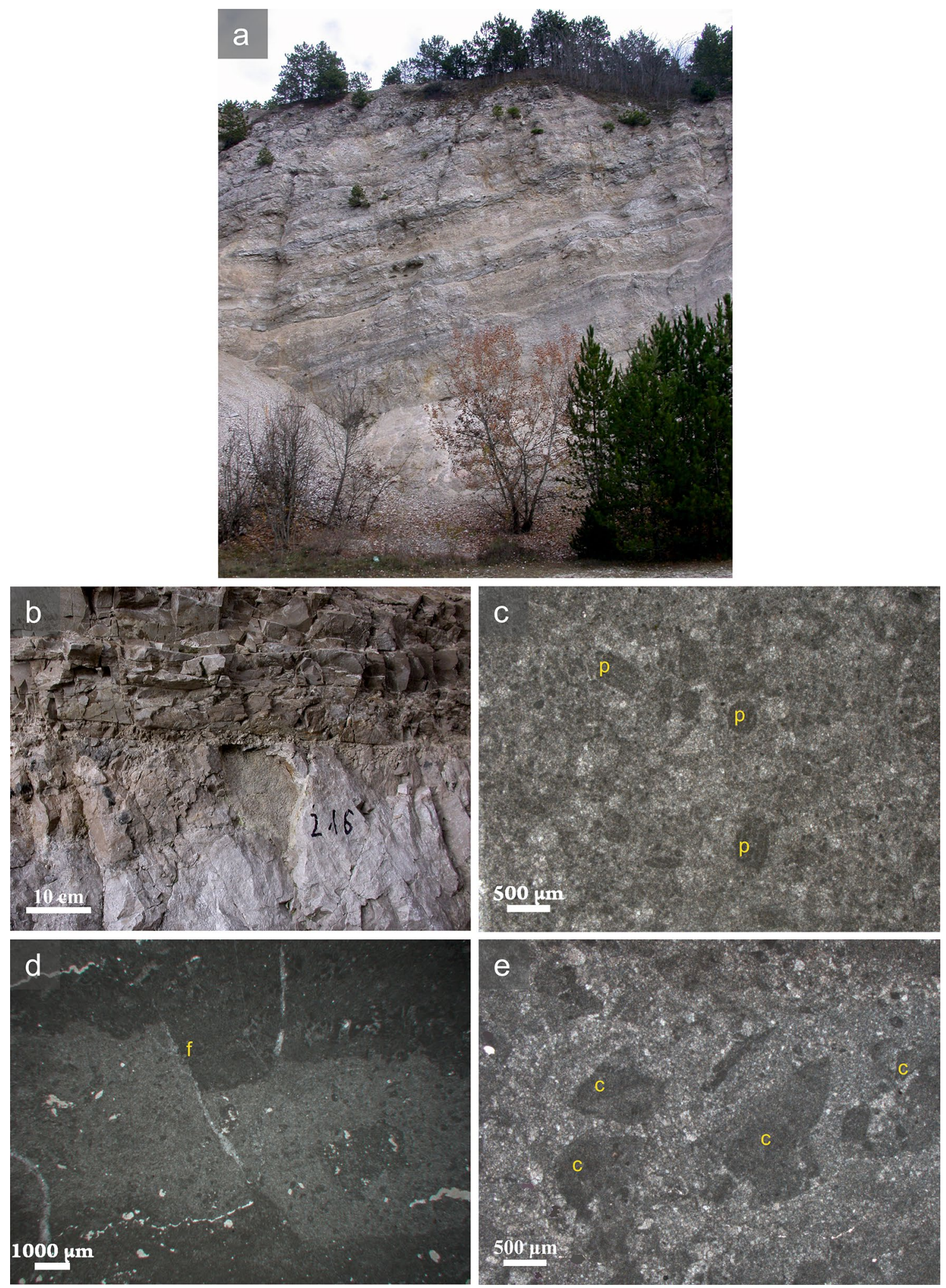

Fig. 9 Petrographic characteristics of the Keszthely-type dolomite exposed in the middle yard of the Gyenesdiás Quarry. a Succession of alternating darker and lighter grey and light brownish grey dolomite beds. b Upper part of a thick light brownish grey bed, containing cm-sized dark grey dolomite clasts (C). c Favreina-type pellets (p) in very finely crystalline matrix (sample 218). d Synsedimentary microfault (f) in laminated fabric (sample 217). e Aphanocrystalline intraclasts (c) in very finely crystalline matrix (sample 216) 


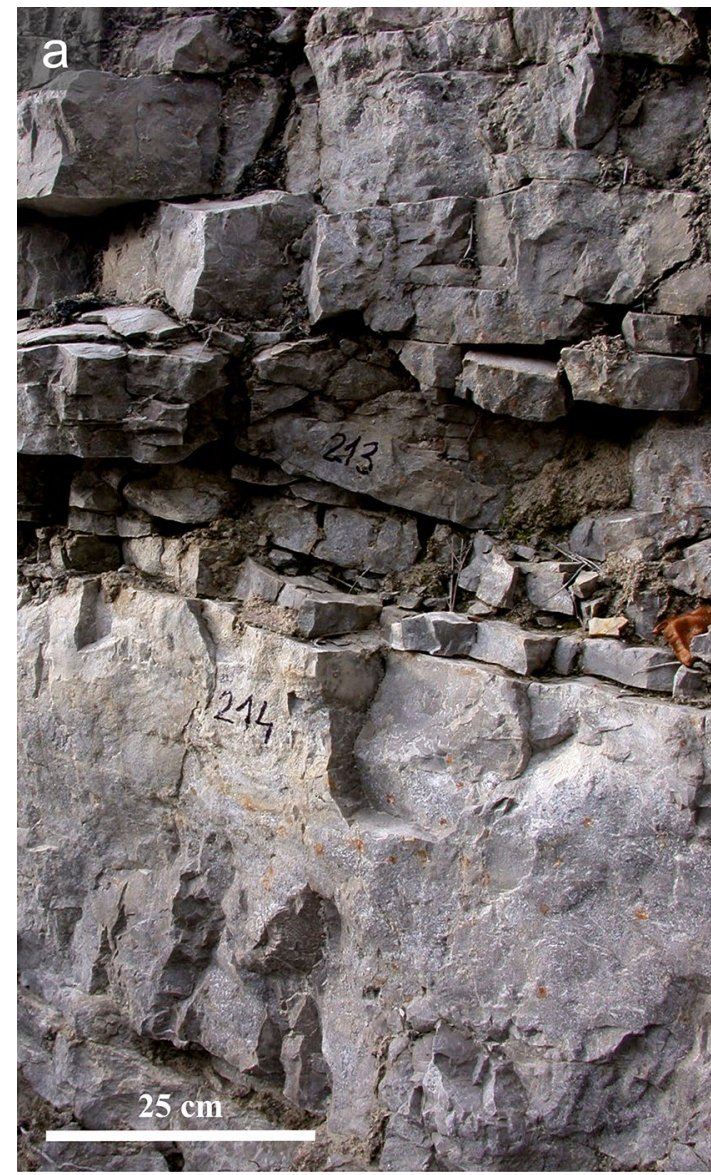

Fig. 10 Depositional structures and petrographic features of the Rezi Dolomite in the western yard of the Gyenesdiás Quarry. a Thickbedded medium grey dolomite is overlain by thin-bedded dark grey dolomite. b Unimodal, finely crystalline dolomite; in which a narrow

whereas the clasts/mottles are darker. In some cases, the crystal size exhibits a gradual change from the matrix to the mottles, whereas in other cases, there is an abrupt crystal size change along a sharp boundary. In most cases, both the matrix and the clasts/mottles are very finely to finely crystalline $(20-60 \mu \mathrm{m})$ fabric-destructive, planar-s dolomite (Online Resource 1). In other cases, the matrix is aphanocrystalline, the clasts/mottles are very finely crystalline (Fig. 12b), and in those cases, where the matrix is finely to medium crystalline (max. $100 \mu \mathrm{m}$ ), finely crystalline (max. $50 \mu \mathrm{m}$ ) clasts/mottles occasionally occur (Online Resource 1; Fig. 12c). The entire fabric exhibits blotchy dull red luminescence (Fig. 12d), where the coarser crystals are brighter (Fig. 12e).

The non-brecciated bed found directly above the abovedescribed rock body exhibits the same features as those below the breccia and no significant difference was found in the fabric and textural characteristics of the medium grey and dark grey, thin-bedded dolomite sampled in other parts of this quarry. From samples taken from the Pilikán Quarry,
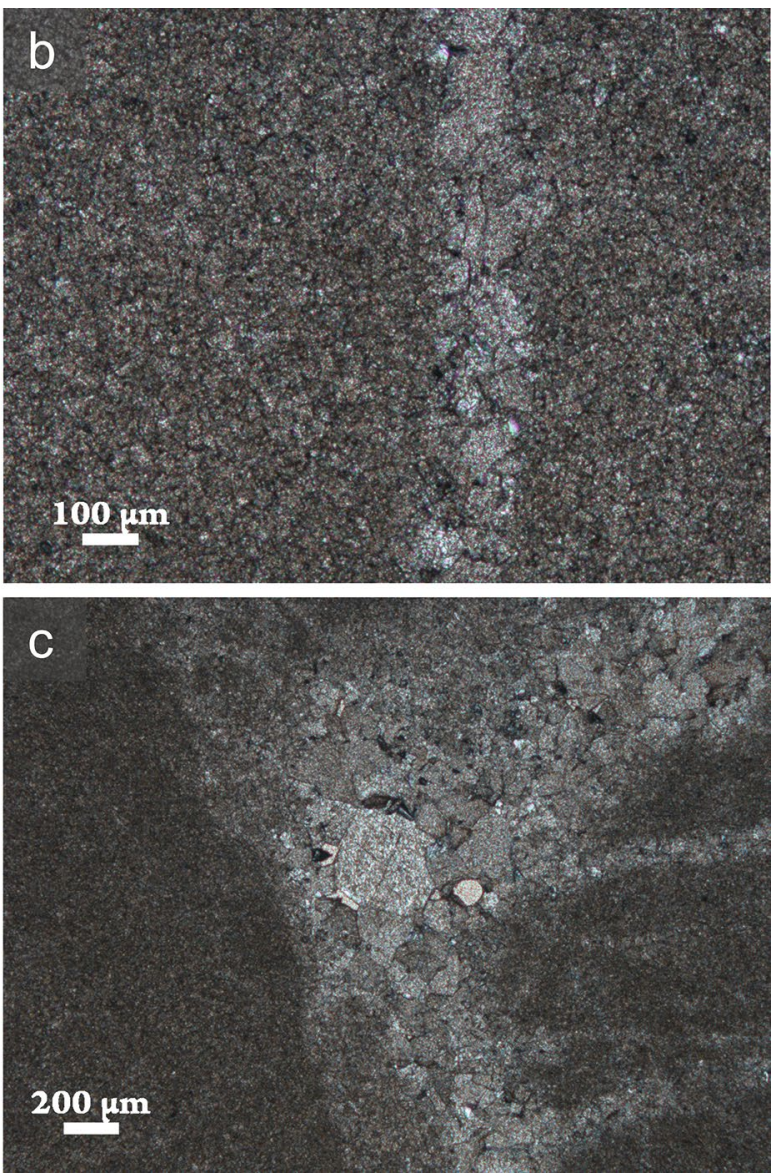

fracture is filled by medium crystalline cement (sample 213). c Wider fracture is filled by medium to coarsely crystalline dolomite cement (sample 214)

in the biomouldic pore- and fracture-filling medium crystalline dolomite cement, less than $3 \mu \mathrm{m}$-sized, irregularly shaped, single-phase, all-liquid fluid inclusions were found (Fig. 13a). The inclusions are arranged in the core of the crystal pointing to primary origin (Fig. 13b).

Above the Fódolomit Formation, with a brecciated tectonic contact, a cc. 20-m-thick part of the Rezi Dolomite is exposed in the Molnárkő Quarry (Fig. 3). Light grey, thin-bedded $(2-5 \mathrm{~cm})$ and laminated dolomite alternates (Fig. 14a). Parallel lamination is prevailing but small-scale slump folds also occur, locally. The thin beds consist of aphanocrystalline to very finely crystalline dolomite. The laminated rocks are made up of alternation of thicker $(3-4 \mathrm{~mm})$ finely crystalline laminae with large amount of micritic intraclasts and thinner $(0.2-0.5 \mathrm{~mm})$ very finely crystalline laminae (Fig. 14b,c). Synsedimentary micro-faults were encountered in the laminated rock type.

The large active Csókakő Quarry is located in the neighbourhood of the Cserszegtomaj Fault (Fig. 3). This structural setting determines the structure of the exposed rock that is 


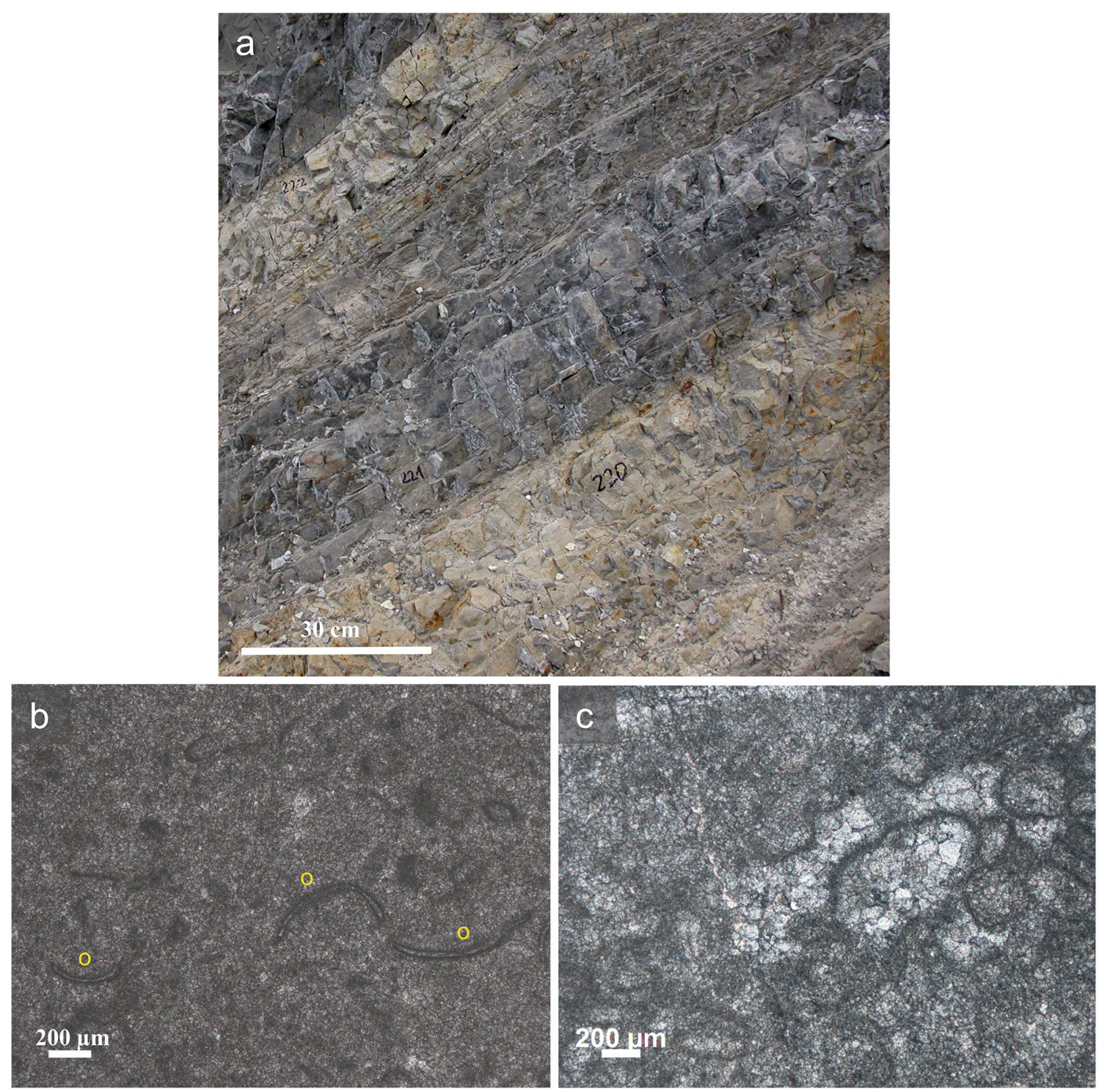

Fig. 11 Depositional structures and petrographic features of the Rezi Dolomite in the eastern yard of the Gyenesdiás Quarry. a Mediumto-thick-bedded and laminated brownish grey and dark grey dolomite.

made up predominantly of brecciated dolomite of various clast sizes from large blocks to $\mathrm{cm}$-sized clasts (scarp breccia; Fig. 15a-c). The rockfall clasts derived from the footwall block and accumulated along the basin margin. Along with lithoclasts, empty or partly cement-filled mouldic pores of cm-to-mm-sized bioclasts (fragments of dasycladalen algae and molluscs) can be observed in these rock bodies (Fig. 15c-e). Intercalating with the breccia bodies, medium to dark grey, thin-bedded, and commonly laminated finely crystalline dolomite bed-sets also occur (Fig. 15a,b,f,g).

Well Rezi Rzt-1 (Fig. 3) intersected the middle and upper members of the Rezi Dolomite and the lower part of the overlying Kössen Formation. The light grey and brownish grey thick-bedded, commonly porous dolomite exposed by b Ghosts of ostracods (yellow o) in finely crystalline matrix (sample 219). c Micritic outline (ghost) of a dasycladalean algae fragment (sample 219)

core samples from the basal part of the well (288-324.4 m) is assigned to the middle member. Breccia fabric characterizes the uppermost $10 \mathrm{~m}$ of this interval, similar to that exposed in the Csókakô Quarry. Centimetre-sized lithoclasts of various fabric, bioclasts (fragments of foraminifera, calcareous sponges, molluscs), micritic nodules, and encrusted bioclasts occur in a finely crystalline matrix (Fig. 16a-d). The dolomite is typified by fine and medium crystals, where the medium crystals have undulose extinction under crosspolars. Many finely crystalline breccia clasts are stained to brown.

The upper member of the Rezi Dolomite (288-265 m) is characterised by dark grey, brownish grey thin-bedded and commonly laminated dolomite. The dolomite is very finely 

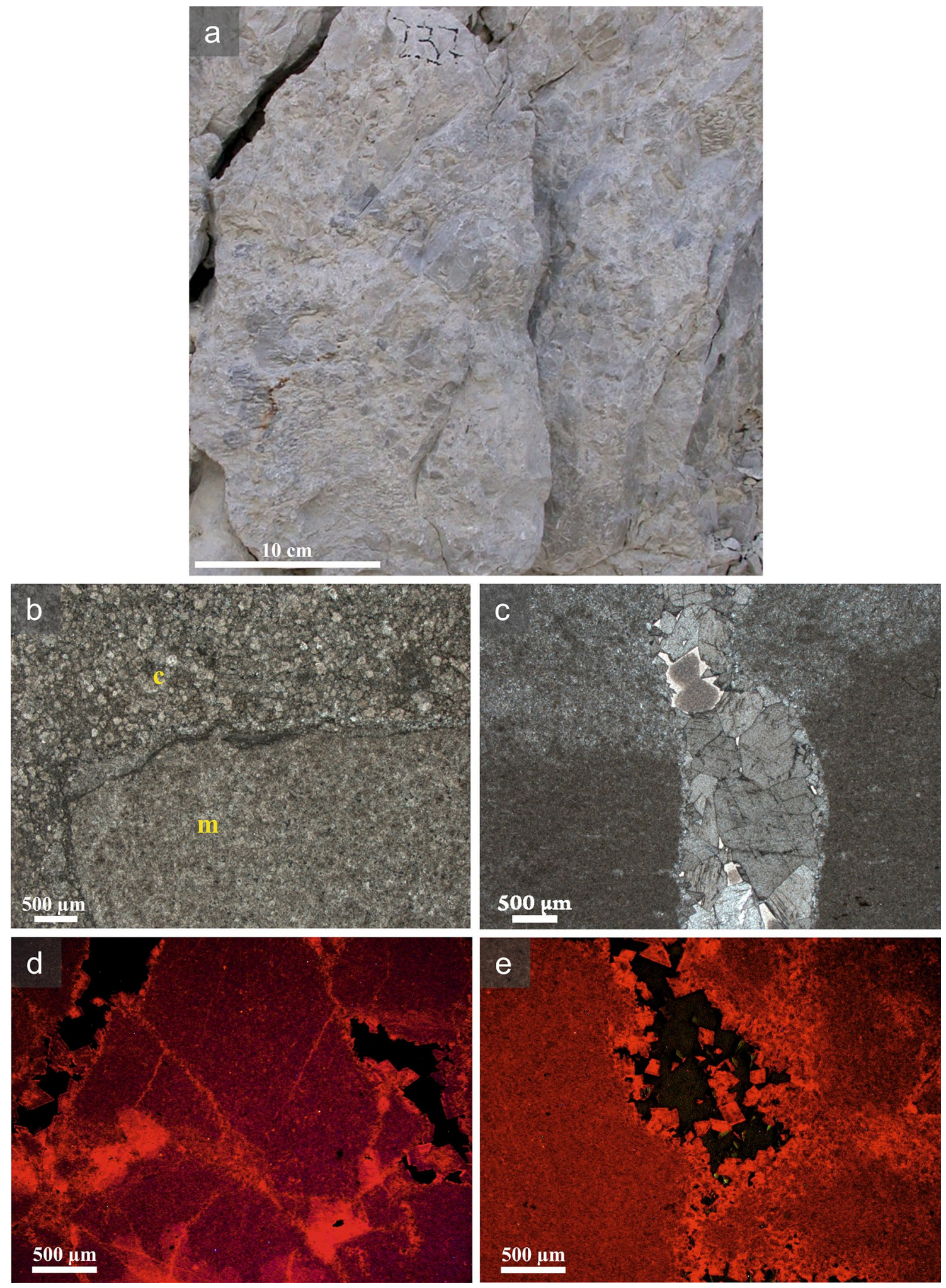

Fig. 12 Petrographic features of the Rezi Dolomite in the Pilikán Quarry. a Matrix supported breccia bed (sample 237). b Matrix supported breccia; the matrix $(\mathrm{m})$ is finely to medium crystalline, the clast (c) is finely crystalline dolomite (sample 238). c Coarsely crystalline fracture-filling cement in aphanocrystalline and finely crystalline fabric destructive dolomite (sample 245). d Cathode-luminescence image of the finely crystalline matrix showing blotchy dull red luminescence (sample 247T). e Cathode-luminescence image of coarser crystalline cement exhibiting bright red luminescence 

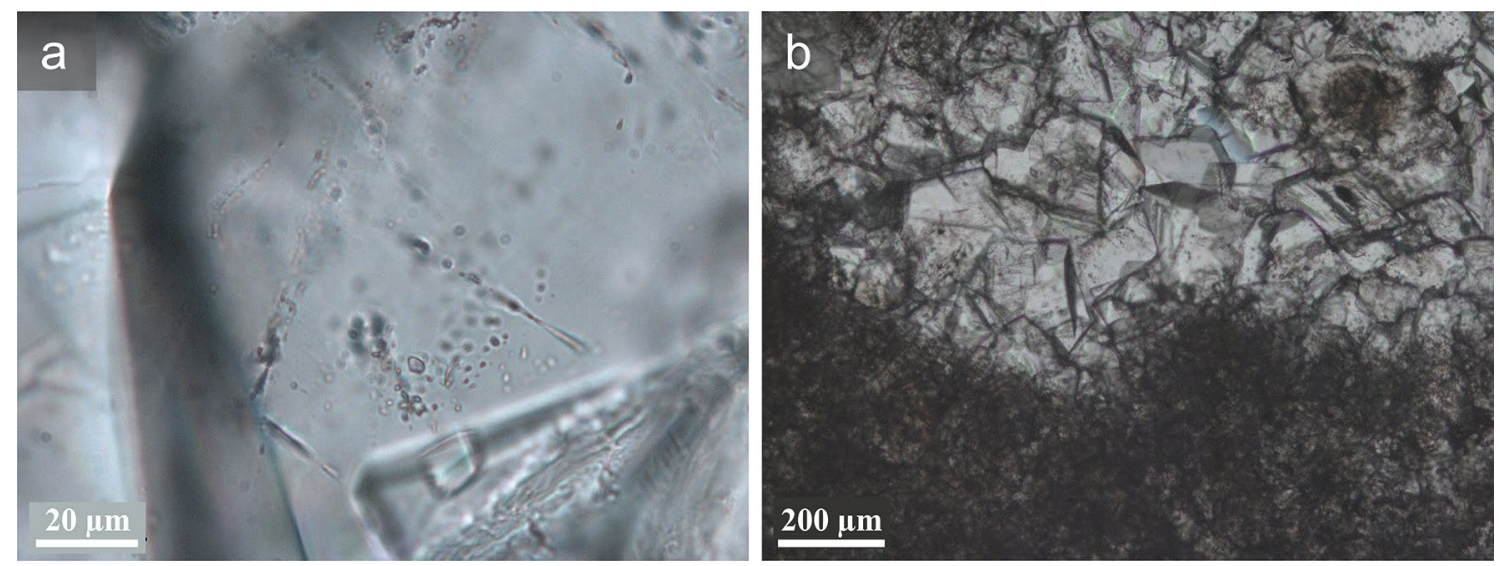

Fig. 13 a Irregularly shaped, single-phase, all-liquid fluid inclusions in the dolomite cement crystals. b. Biomouldic pore-filling medium crystalline dolomite cement (sample 242)

crystalline, the sedimentary fabric is well-preserved, usually mudstone with scattered peloids and foraminifera. Coalified plant fragments are common. The quantity of bioclasts significantly increases in the upper part of this member. Argillaceous dolomite with lithoclastic dolomite interbeds occurs in the uppermost part of the formation that is overlain by dark grey marl belonging to the overlying Kössen Formation.

\section{Stable carbon and oxygen isotopes}

The results of the stable isotope analyses are presented in Online Resource (Tables 1 and 2) and Fig. 17. Separate measurement of the matrix, certain fabric elements and the cement was carried out where possible. The samples taken from the Lofer cyclic Fődolomit Formation in the Szépkilátó Quarry yielded $\delta^{18} \mathrm{O}$ values between +0.2 and $+0.5 \%$ o and $\delta^{13} \mathrm{C}$ values between +3.2 and $+3.8 \%$. There is no significant difference between the values of the $\mathrm{B}$ and $\mathrm{C}$ members of the Lofer cycle. Values of $\delta^{18} \mathrm{O}-0.7$ to $+0.7 \%$ and $\delta^{13} \mathrm{C}+2.9$ to $+3.6 \%$ were measured on samples taken from the"Keszthely-type dolomite" unit in the middle yard of the Gyenesdiás Quarry. The separately sampled fracture-filling cement yielded values $\delta^{18} \mathrm{O}-1.8 \%$ and $\delta^{13} \mathrm{C}+2.9 \%$.

The samples taken in the Gyenesdiás Quarry from the lower part of the Rezi Dolomite yielded $\delta^{18} \mathrm{O}$ values between +0.1 and $+1.7 \%$ and $\delta^{13} \mathrm{C}$ values between +1.8 and $+3.3 \%$. Carbon elemental percentage and isotope values of bulk organic matter (Total Organic Carbon, TOC) were determined on five samples. The amount of TOC varies between 0.035 and $0.256 \%$. The $\delta^{13} \mathrm{C}_{\mathrm{TOC}}$ values ranges from -25.0 to $-28.1 \%$ o. The fracture filling cement from here yielded values $\delta^{18} \mathrm{O}-3.7 \%$ and $\delta^{13} \mathrm{C}+1.8 \%$. The values for the samples taken from the Pilikán Quarry are as follows: $\delta^{18} \mathrm{O}-0.1$ to $+0.8 \%$ and $\delta^{13} \mathrm{C}+1.7$ to $+2.8 \%$. The range of the values for the fracture filling cement: $\delta^{18} \mathrm{O}-3.7$ to $-7.6 \%$ and $\delta^{13} \mathrm{C}+1.5$ to $+2.0 \%$. Values of $\delta^{18} \mathrm{O}+0.3$ to $+1.5 \%$ and $\delta^{13} \mathrm{C}+0.9$ to $+2.3 \%$ were measured on samples taken in the Molnárkő Quarry from the Rezi Dolomite.

\section{Strontium isotope ratios}

${ }^{87} \mathrm{Sr} /{ }^{86} \mathrm{Sr}$ ratios were measured on selected samples (Online Resource, Table 3) to determine the origin and age of the dolomitizing fluids. For this aim 1 sample was taken from the Lofer-cyclic facies of the Fôdomit Formation derived from the Szépkilátó Quarry, 4 samples from various texture types of the "Keszthely-type dolomite" unit of the Gyenesdiás Quarry, one sample from the laminated version of the Rezi Dolomite exposed in the Molnárkô Quarry, and one sample from the thick-bedded, brecciated facies of the Rezi Dolomite of the Pilikán Quarry. The measured ${ }^{87} \mathrm{Sr} /{ }^{86} \mathrm{Sr}$ ratios are within a range of 0.707738 and 0.708128 (Table 3 Online Resource 1 and Fig. 18).

\section{Interpretation and discussion}

Our petrographic and geochemical investigations suggest that in the cases of all of the studied rock bodies (the Lofercyclic and the "Keszthely-type" Fódolomit Formation and the Rezi Dolomite Formation) the pervasive dolomitization of the precursor carbonate sediments took place during the early diagenesis, and seawater of more or less modified chemical composition was the dolomitizing fluid. During the investigated time range from the Middle to Late Norian the study area was located far from the open ocean, in the continent-ward belt of a wide carbonate platform which transformed to a back-platform basin system (Haas and Budai 1995; Haas 2002), and during this time interval the climatic conditions gradually changed from semi-arid to semi-humid (Haas et al. 2012, 2017). These paleogeographic conditions 


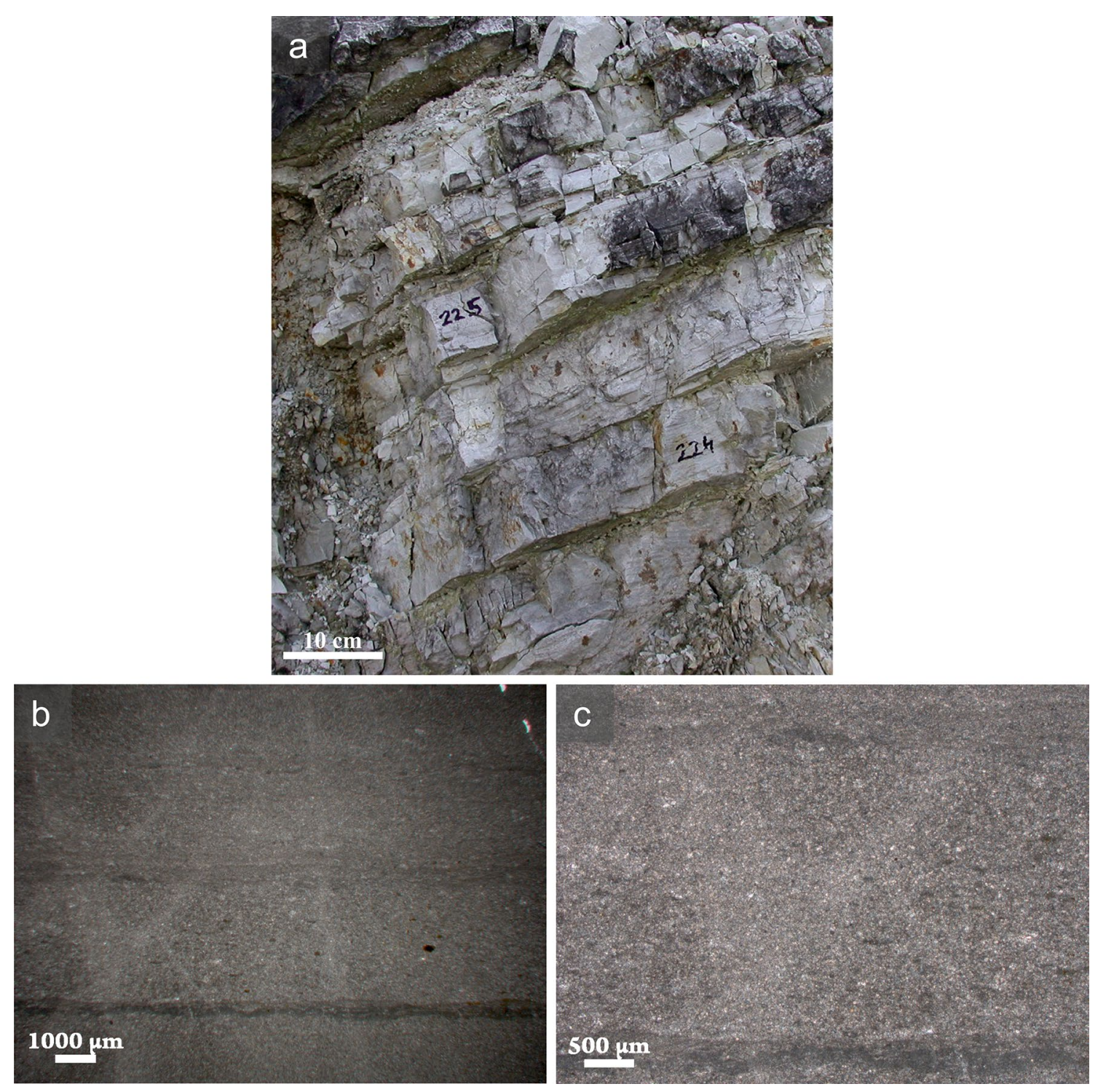

Fig. 14 Depositional structures and petrographic features of the Rezi Dolomite in the Molnárkő Quarry. a Thinly bedded dolomite with laminated intervals. b Alternating thicker finely crystalline and thin-

must be taken into consideration for the evaluation of the dolomitization processes.

The $\delta^{18} \mathrm{O}$ values measured on the samples of the Fôdolomit Formation $(+0.2$ to $+0.5 \%$ ) are slightly less positive than those measured on the samples taken from the same formation in other parts of the TR (Bakony and Vértes Mts.). However, similar values were measured on the dolomite samples of the Fenyőfő Member that is a transitional unit between the Fódolomit Formation and the Dachstein Limestone, made up of alternation of dolomitized, partially dolomitized and non-dolomitized beds (Haas et al. 2015). The $\delta^{13} \mathrm{C}$ values $(+3.2$ and $+3.8 \%$ ) fit to the range of those of the Födolomit Formation in other part of the TR (Haas et al. 2017). ner very finely crystalline laminae (sample 224). c Thicker laminae consist of silt-sized carbonate grains and fine sand-sized micritic intraclasts (sample 224)

The stable isotope values measured for the Lofer-cyclic Fődolomit and thick-bedded"Keszthely-type dolomite" do not significantly differ from one another; the $\delta^{18} \mathrm{O}$ values are between -0.7 and $+0.7 \%$ and the $\delta^{13} \mathrm{C}$ values are between +2.9 and $+3.6 \%$ (Fig. 17). The $\delta^{18} \mathrm{O}$ range suggests near-surface dolomitization. The $\delta^{13} \mathrm{C}$ values are within the range of the Norian seawater determined by Korte et al. (2005). $\delta^{13} \mathrm{C}$ values between +3.0 and $0 \%$ were measured on the samples taken from the Middle Norian pelagic limestones in the Western Neotethys key-section Pizzo Mondello, Sicily (Muttoni et al. 2014). Although the values measured for the roughly coeval Fődolomit Formation in the Keszthely Mts. are slightly more positive, the difference is not significant and seems 

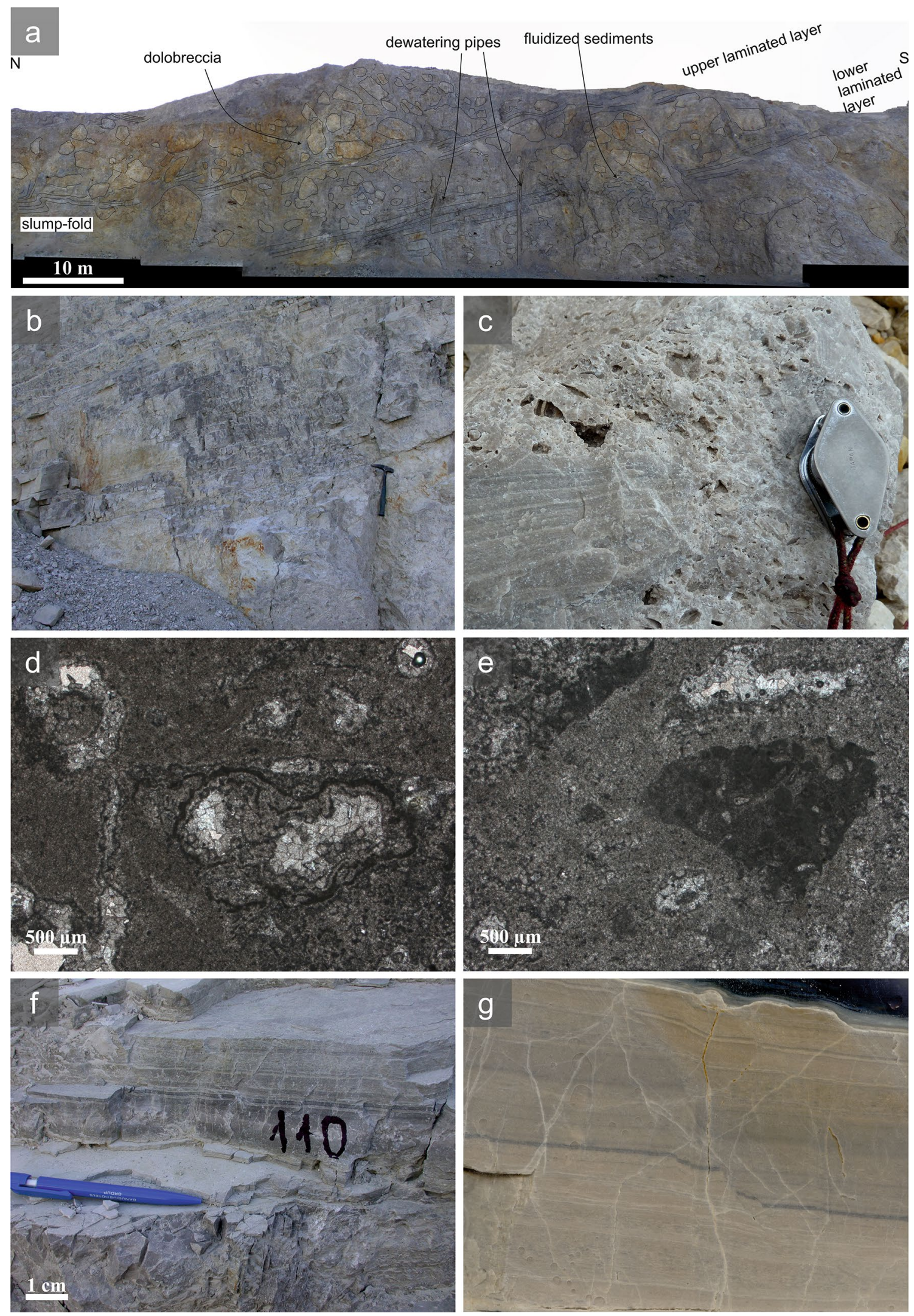
4Fig. 15 Depositional structures and petrographic features of the Rezi Dolomite in the Csókakő Quarry. a Brecciated dolomite (scarp breccia) with thin bedded dolomite intercalations. b Breccia body is overlain by thin-bedded dolomite. c Breccia contains a dm-sized clast derived from a laminated bed, small lithoclasts and moulds of bioclasts, partially filled by dolomite cement. $\mathbf{d}$ Cement-filled moulds of dasycladalean algae, and microbial nodule in very finely crystalline dolomite (sample 111). e Miritic lithoclast in clotted very finely crystalline dolomite matrix (sample 111). f Closer view to a laminated finely crystalline dolomite bed (sample 110). g Cut surface of the laminated finely crystalline dolomite (sample 110)

to confirm the seawater origin of the dolomitizing fluid. For the samples taken from the matrix of the Fondolomit Formation in various part of the TR, $\delta^{18} \mathrm{O}$ values +0.5 to $+3.1 \%$ and $\delta^{13} \mathrm{C}+1.2$ to $+3.8 \%$ were measured (Haas et al. 2015,2017$). \delta^{18} \mathrm{O}$ values between +0.6 and $+3.0 \%$ o and $\delta^{13} \mathrm{C}$ values between 0 and $+3.0 \%$ were reported by Iannace and Frisia (1994), while $\delta^{18} \mathrm{O}-3.9 \%$ o to +1.7 and $\delta^{13} \mathrm{C}+2.4$ to $+2.9 \%$ values were recently measured by Berra et al. (2020) for the Dolomia Principale in the Southern Alps, Lombardy. These values do not show significant difference from those of the Fődolomit Formation of the Keszthely Mts. suggesting that the near-surface dolomitization took place under similar paleogeographic conditions.

In the case of the Middle Norian Lofer-cyclic development of the Fôdolomit Formation, the carbonate deposition took place on the wide and levelled internal belt of the carbonate platform developed along the passive margin of the Neotethys Ocean. The high-frequency sea-level oscillation led to alternation of subtidal and peritidal depositional conditions which were periodically interrupted by subaerial exposures. Shallow marine calcareous sediments were deposited during the high sea-level phase of the cycles. In the low sea-level phase fenestral laminated microbial boundstone (stromatolite) beds were formed. Precipitation of $\mathrm{Mg}-\mathrm{Ca}$ carbonates (very-high magnesian calcite-VHMC) might have initiated already in the microbial mat. The crystal morphology of the pore-lining cement suggests that blocky calcite was the first cement generation in the fenestral pores.

Further sea-level lowering led to the establishment of supratidal conditions over large parts of the area. Under semi-arid climate this environmental setting may have been favourable for reflux of seawater-derived mesohaline fluids (37-48\%o), which resulted in pervasive dolomitization (Haas et al. 2015, 2017). Based on the results of transport modelling slight increase in salinity can drive fluids through underlying sediments and may cause pervasive reflux dolomitization (Jones and Xiao 2005; Manche and Kaczmarek 2019). The near-surface early replacive dolomitization may have affected the carbonate sediments, and also the previously precipitated pore-lining calcite cement. Coarser crystalline dolomite cement occluded the larger fenestral pores and fractures later, in the course of burial.

The precursor lime mud of the "Keszthely-type dolomite" unit may have been deposited permanently in the deeper part of the subtidal zone although probably still within the euphotic zone. Accordingly, the sea bottom remained below the intertidal zone even during the periods of the low sea levels (Fig. 19). This deepening trend can be interpreted as an indicator of an increase in the subsidence rate that is accompanied with synsedimentary faulting, i.e., incipient phase of the basin evolution. Roughly contemporaneously with this, during the latest Middle Norian to early Late Norian changes commenced also in the climate; the long-lasting permanent semi-arid regime was followed by changing semi-arid and semi-humid periods (Haas et al. 2012). In the platform, surviving north-east from our study area, this is reflected in ephemeral and commonly partial dolomitization of the platform carbonate successions (Fenyőfő Member). As a consequence of the basin evolution the direction of flux of platform-derived slightly evaporated seawater turned towards the newly formed back-platform basin at least in its neighbourhood. It means that the reflux model can be applied also for the dolomitization of the shallow subtidal carbonate succession of the "Keszthely-type dolomite". The isotope geochemical data seems to support this interpretation. The observed slight negative shift in the $\delta^{18} \mathrm{O}$ values in the samples of the "Keszthely-type dolomite" unit might be explained by periodically changing influence of meteoric water. The synsedimentary fracturing may have promoted the flux of the dolomitizing fluid.

During the Late Norian the development of the extensional basin (Kössen Basin) accelerated in the continentward belt of the huge Late Triassic carbonate platform system. Listric fault-controlled half grabens (sub-basins) came into existence (Haas 2002). Similar fault-controlled basins were formed coevally above the Dolomia Principale in the western Southern Alps (Jadoul et al. 1994, 2004; Berra et al. 2020). In the depocenter of the largest basin (Lake Idro area, eastern Lombardy) a nearly 1-km-thick succession of wellbedded, finely crystalline dolomite and limestone (Aralalta Group) was formed, which is overlain by organic-rich shales of the Riva di Solto Formation. Near the basin margins the sedimentation was characterised by gravity flows and slumps (Jadoul et al. 1994, 2004). West to this basin the Dolomia Principale platform was subaerially exposed in the Late Norian. Then in the latest Norian small basins began to form where the Riva di Solto Formation deposited directly above the Dolomia Principale (Berra et al. 2010, 2020). In the late Middle Norian fault controlled restricted basin developed also in the Northern Calcareous Alps, where the Seefeld Formation was formed with brecciated marginal facies and organic-rich clayey dolomite internal basin facies (Donofrio et al. 2003; Kustatscher et al. 2017) that can be correlated 

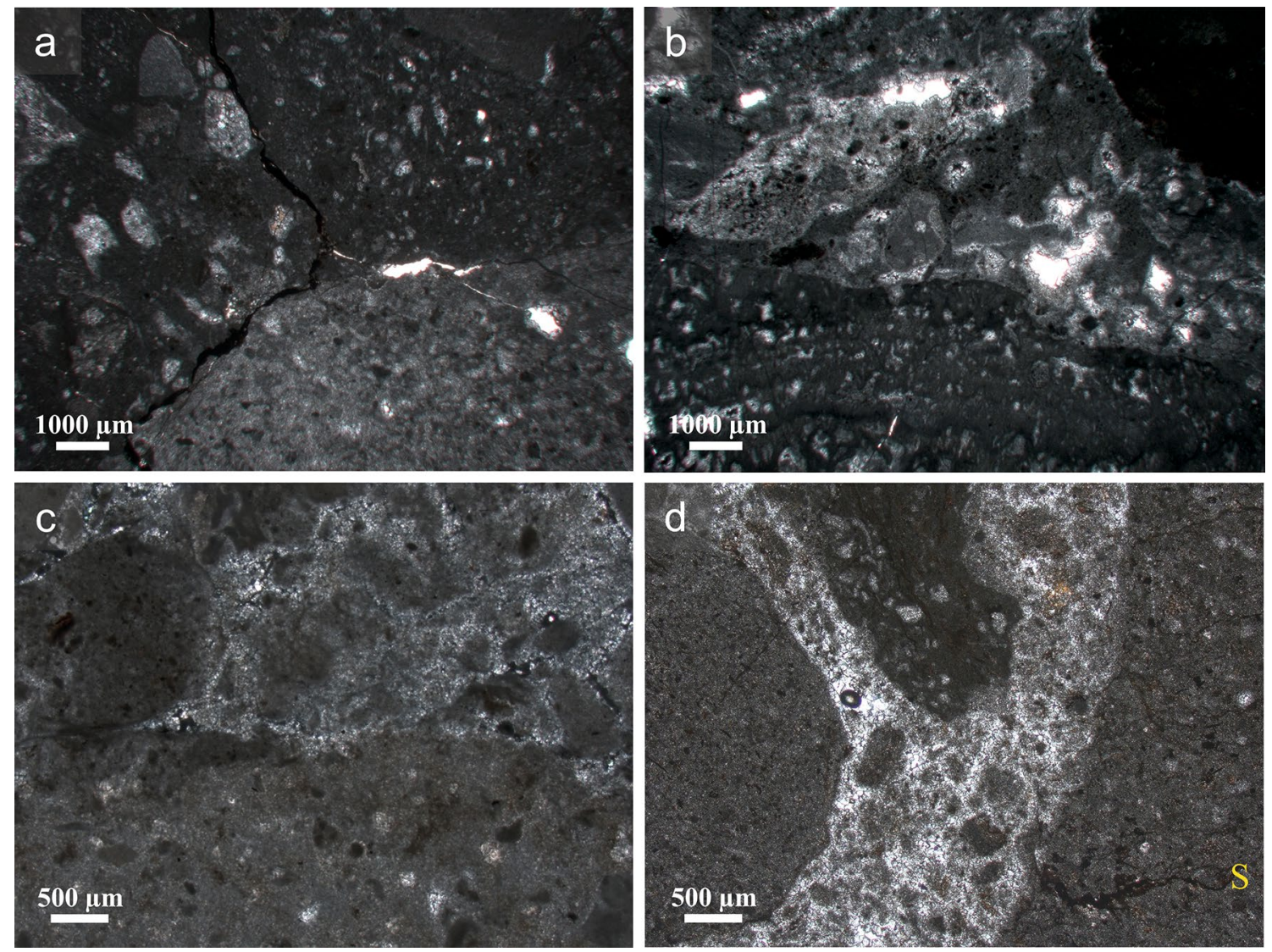

Fig. 16 Petrographic features of a breccia body intersected in core Rezi-1. a Centimetre-sized dolomite lithoclast in aphanocrystalline dolomite matrix with mm-sized lithoclasts and biomoulds occluded by very finely crystalline cement. The larger clast consists of very finely crystalline dolomite exhibiting poorly preserved sedimentary fabric $(303 \mathrm{~m})$. b Centimetre-sized fragment of a well-preserved calcareous sponge, microbial micritic nodule and small micritic clasts. Intergranular pores are lined by very finely crystalline dolomite and

with the lower member of the Rezi Dolomite. The Seefeld Formation was covered by the upper unit of the Hauptdolomit Group which may correspond with the middle member of the Rezi Dolomite. It was followed by the deposition of the Plattenkalk (Donofrio et al. 2003) formed in basin setting, akin to that of the upper member of the Rezi Formation prior to the onset of the deposition of the Kössen Formation.

The Cserszegtomaj Fault was the western boundary of the sub-basin developed in the Keszthely Mts. It was an asymmetric basin with a steep erosional slope along the western master fault, and a wide low-angle slope on the northeastern side of the sub-basin towards the large Dachstein Platform (Fig. 19). Redeposited shallow marine gastropods and bivalves reported from the Csókakő Quarry (Budai and Koloszár 1987) indicate the prolongation of shallow marine conditions on the western, footwall side of the Cserszegtomaj Fault. Unsorted breccia exposed in the Csókakő Quarry is interpreted to be debris-flow and hyper-concentrated flow. partially filled by medium crystalline dolomite cement $(288 \mathrm{~m})$. c Dolomite lithoclasts of various sizes, exhibiting poorly preserved sedimentary fabric. Finely crystalline cement occurs in the intergranular pores. $(288 \mathrm{~m})$. d Very finely crystalline breccia clasts of various sizes, which are surrounded by finely to medium crystalline dolomite cement. The dissolution seam $(\mathrm{S})$ is visible in one of the clasts, which does not extend beyond the clasts $(297 \mathrm{~m})$

These gravity mass transport deposits were accumulated along the toe of the steep slope. The deposition of the breccia body intersected in core Rzt-1 below the thin-bedded dolomite succession (upper member of the Rezi Dolomite) may also be related to the vicinity of the basin-bounding fault zone. The relatively deep internal part of the sub-basin was the site of the deposition of the precursor carbonate sediments of the lower and upper members of the Rezi Dolomite (Fig. 19). The ambient carbonate platforms (mostly the large Dachstein Platform) may have been the source of a predominant part of the fine-grained carbonate sediment. The thin-shelled bivalves and ostracods may have thrived on the gently sloping bottom of the basin. The relatively high total organic carbon (TOC) content and millimetre scale lamination in some beds indicate the establishment of dysoxic to anoxic conditions in the lower stagnant water layer that may have got enhanced salinity during the more restricted periods of the basin. On the other hand, the conodonts found in some 


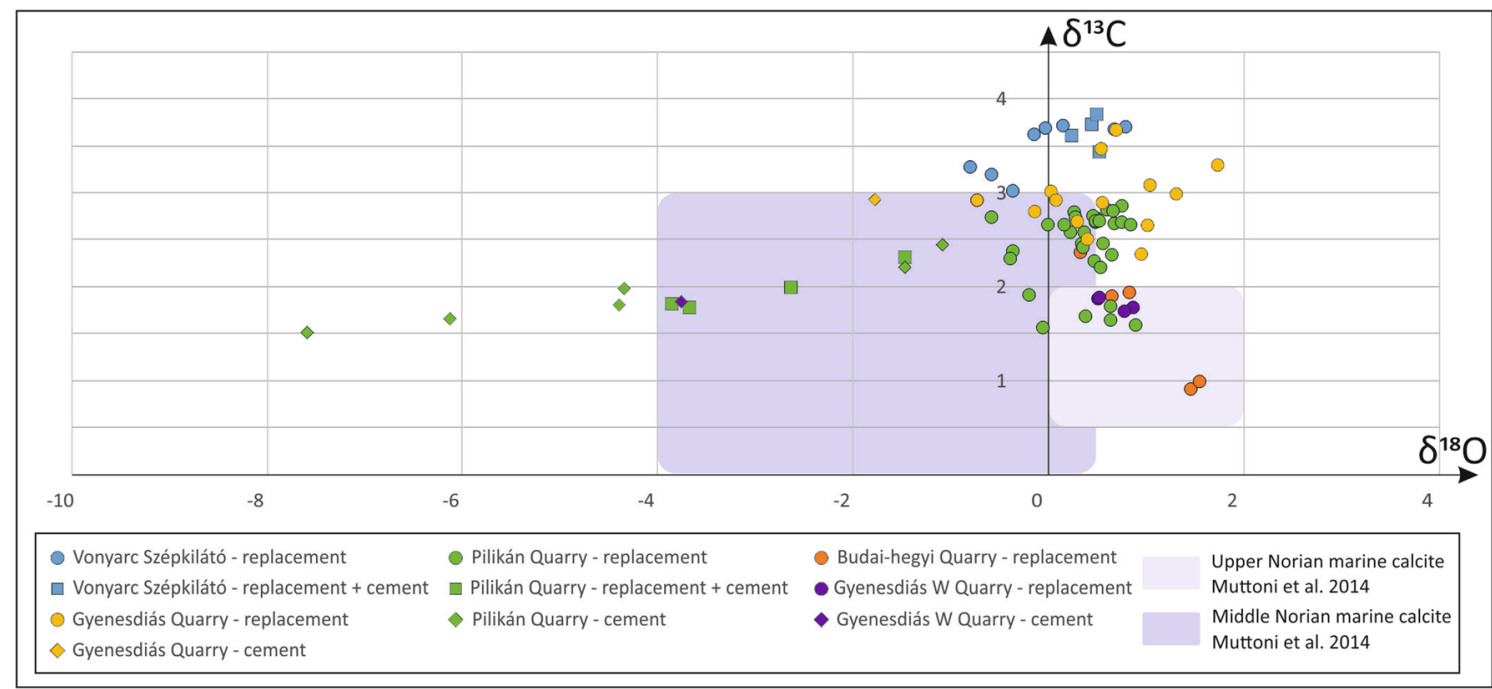

\begin{tabular}{|lll|}
\hline$\bigcirc$ replacement & Vonyarc Szépkilátó & Pilikán Quarry \\
$\square$ replacement + cement & Gyenesdiás Quarry & Budai-hegyi Quarry \\
$\diamond$ cement & Gyenesdiás W Quarry & \\
\hline
\end{tabular}

Fig. $17 \delta^{13} \mathrm{C}$ and $\delta^{18} \mathrm{O}$ values measured on dolomite samples taken from the studied sections. Lithostratigraphic assignment and petrographic features of the measured samples are presented in Online Resource 1

Fig. 18 Comparison of ${ }^{87} \mathrm{Sr} /{ }^{86} \mathrm{Sr}$ values presented by Korte et al. (2003) from Triassic brachiopods and conodonts of the Tethyan and Germanic Basin realms and those that were measured on selected samples taken from the studied Upper Norian succession (yellow dots). Phanerozoic reference curve of secular changes in marine ${ }^{87} \mathrm{Sr} /{ }^{86} \mathrm{Sr}$ isotope ratio (Nebel and Stammeier 2018; based on Veizer et al. 1999) is presented on the inset diagram

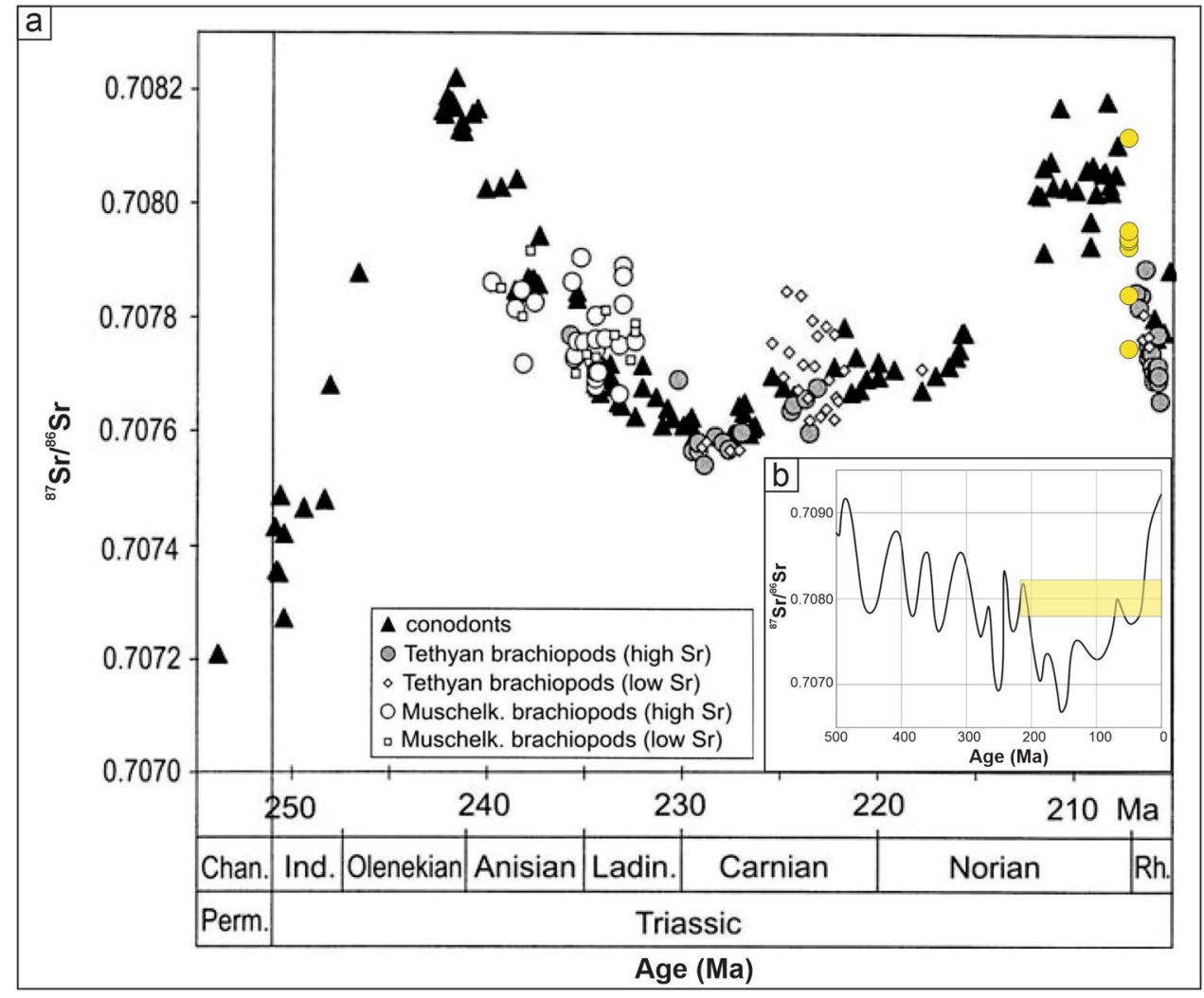

beds (Budai and Kovács 1986) indicate oxic normal marine conditions in the upper water layer at least during periods of high sea level. However, according to recent comparative
Conodont studies performed in various facies areas of the western Neotethys (Du et al. 2021), the Mockina slovakensis may have been a surface dweller species living in different 
SW

NE

Keszthely Mts.

Bakony

latest Norian

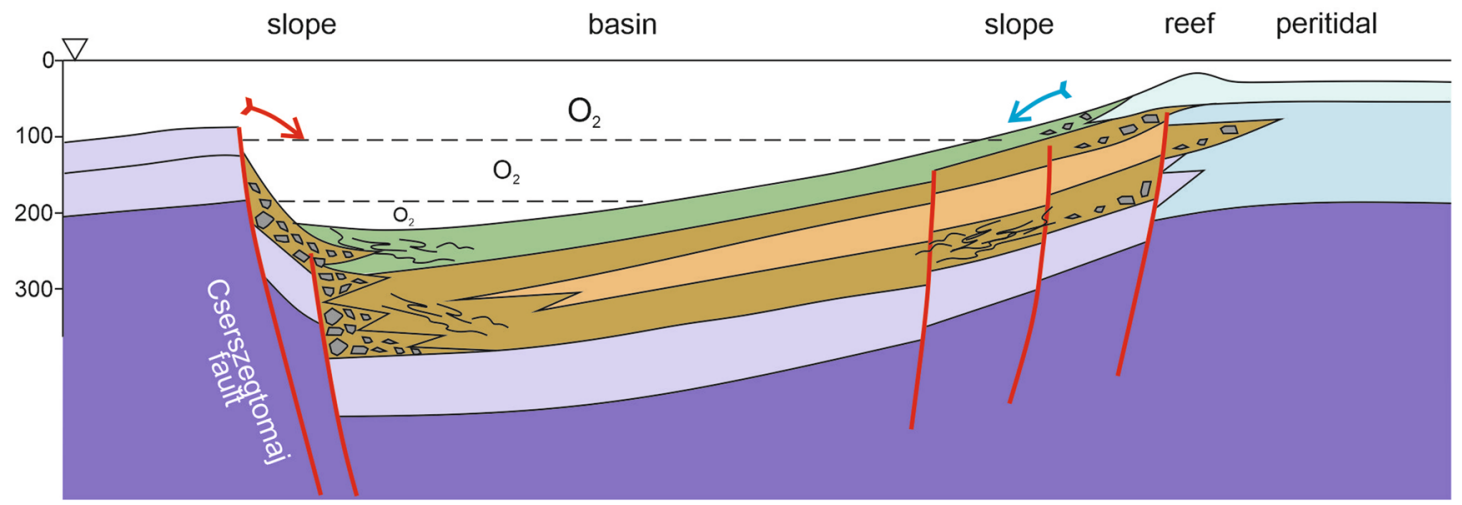

Late Norian
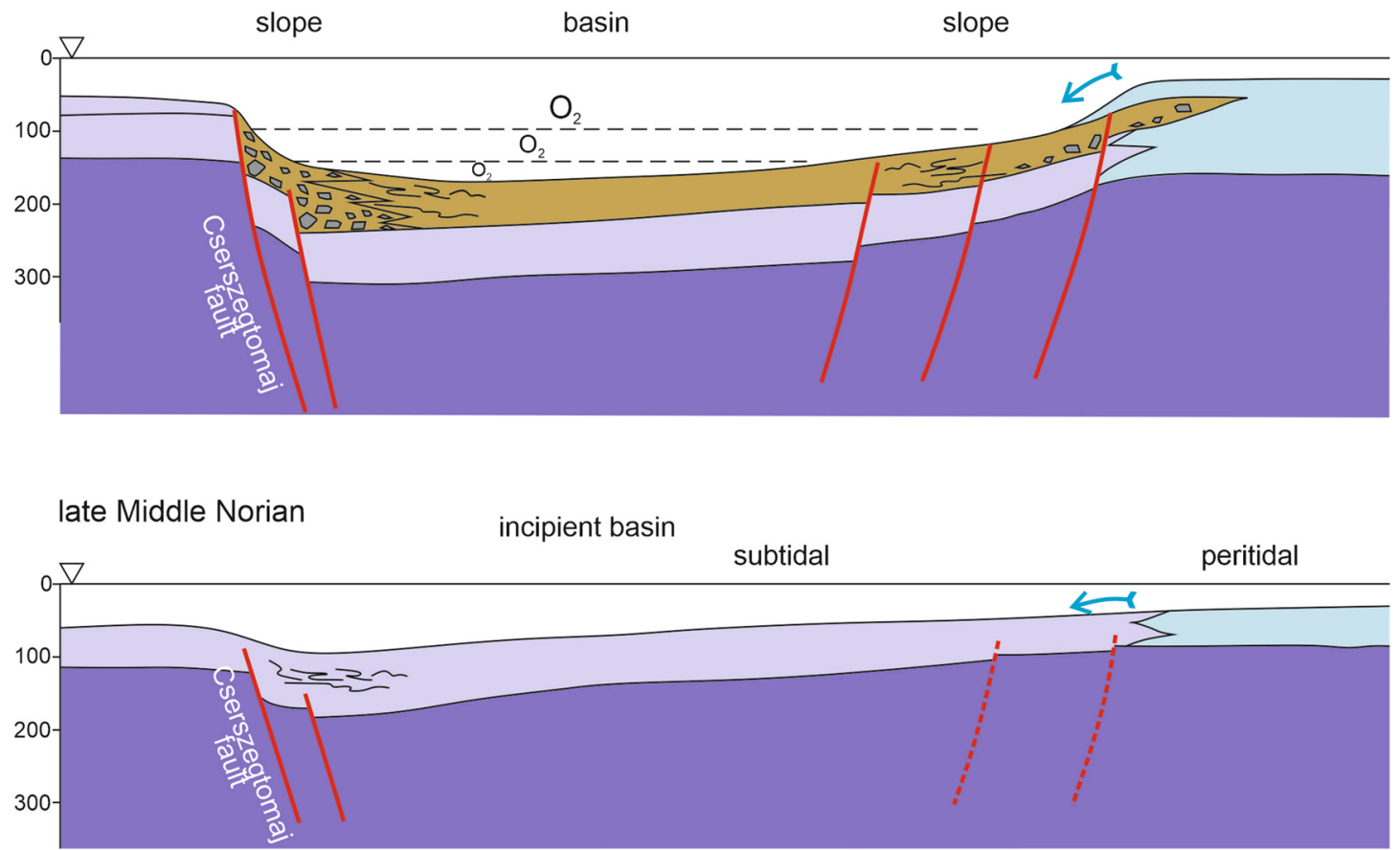

Middle Norian

peritidal inner platform / ramp

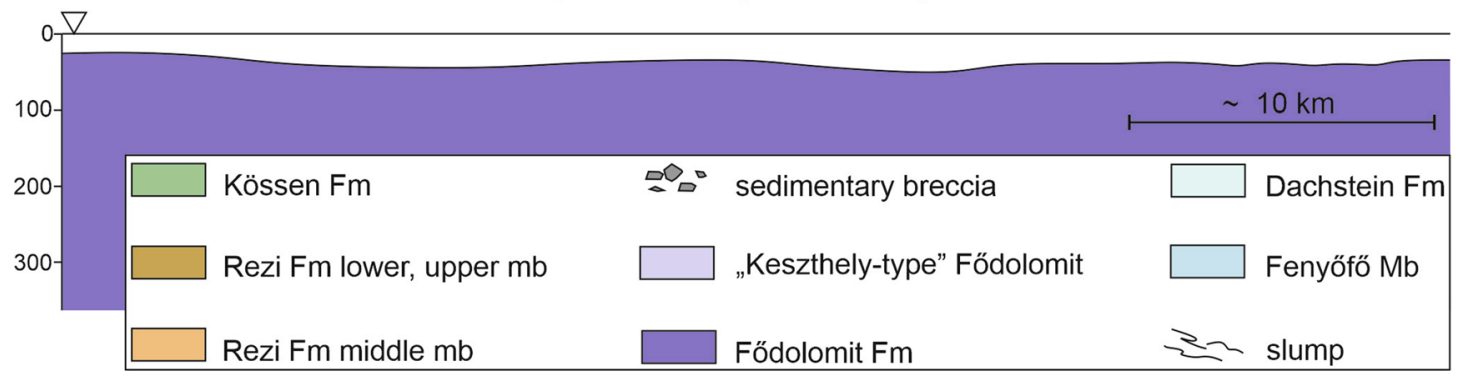


4Fig. 19 Evolution of the back-platform basin during the Late Triassic in the southwestern part of the Transdanubian Range. The size of $\mathrm{O}_{2}$ symbols refers to the oxygen content of the water. The blue arrow indicates platform-derived carbonate input; the red arrow indicates terrigenous siliciclastic input

environments, from pelagic deep basins to shallow water carbonate platforms, and not only in back-platform restricted basins.

The $\delta^{18} \mathrm{O}$ values measured on the matrix of the Rezi Dolomite (between -0.1 and $+1.7 \%$ ) are in harmony with the concept of near normal marine dolomitizing fluid (Fig. 17). The measured ${ }^{87} \mathrm{Sr} /{ }^{86} \mathrm{Sr}$ ratios support this interpretation. According to the data set of Korte et al. (2003) there is a definite trend in the ${ }^{87} \mathrm{Sr} /{ }^{86} \mathrm{Sr}$ ratio from the Carnian towards the uppermost Norian reflecting increasing radiogenic $\mathrm{Sr}$ isotopic composition of seawater that is followed by an abrupt shift towards the more unradiogenic ${ }^{87} \mathrm{Sr} /{ }^{86} \mathrm{Sr}$ values in the Rhaetian (Fig. 18). Recent detailed studies performed in pelagic deep shelf successions in the Northern Calcareous Alps, Austria coeval with the "Keszthely-type dolomite" and the lower member of the Rezi Dolomite sequences confirmed this very characteristic trend (Kovács et al. 2020), since the range of ${ }^{87} \mathrm{Sr} /{ }^{86} \mathrm{Sr}$ ratios measured on the samples derived from the upper part of the cyclic beds of the Födolomit Formation, the "Keszthely-type dolomite" unit and the Rezi Dolomite, respectively, fits well into the range of the upper Middle Norian to Upper Norian values (Fig. 18).

The predominantly platform-derived precursor carbonate sediments of the lower and upper members of the Rezi Dolomite were accreted in the internal parts of fault-bounded semi-restricted sub-basins in the advanced phase of the development of the Kössen Basin during the Late Norian (Fig. 19). The early diagenetic fabric-retentive dolomitization took place in shallow burial setting and seawater (probably of slightly enhanced salinity) was the dolomitizing fluid. The extensional structural regime may have contributed to the dolomitization. In the partially dolomitized sediment a fracture network came into being, which promoted the flux of seawater and whereby the continuation of the replacive dolomitization. Along the synsedimentary fracture network larger dolomite crystals were formed than in the previous phases.

The $\delta^{13} \mathrm{C}$ values ( +0.9 to $+2.8 \%$ ) measured on the lower member of the Rezi Dolomite show a negative shift, compared to the Fődolomit Formation. Although in the studied sections of the Rezi Dolomite the organic content of the rocks was relatively low, the contribution of the organogenic dolomitization, i.e., the role of bacterial sulfate reduction and methanogenesis in overcoming the barriers of dolomite nucleation (Mazzullo 2000) cannot be excluded. On the basis of the measured $\delta^{13} \mathrm{C}$ values, the organogenic dolomitization might have taken place in the uppermost part of the zone of bacterial methanogenesis. However, for the evaluation of the $\delta^{13} \mathrm{C}$ values we must keep in mind that +0.5 to $+2.0 \%$ o were measured on the samples taken from the Upper Norian part of the pelagic limestone in the Western Neotethys keysection Pizzo Mondello, Sicily (Muttoni et al. 2014) which do not differ significantly from those of the Rezi Dolomite. Therefore, in our opinion it is more probable that the measured values reflect the dominance of platform derived precursor carbonate fraction.

As to the dolomitization of the fault-bounded debris flow deposits, based on data of core Rzt-1, it can be supposed that the redeposited clasts of various origin and preceding diagenetic history were subject of dolomitization near the boundary of shallow and deep burial diagenetic settings (100-200 m) parallel with onset of chemical compaction.

The lithologic features of the upper member of the Rezi Dolomite are similar to those of the lower member although the poor exposure conditions did not allow the detailed study of this interval. Based on studies on cores (e.g., Rzt-1), there is a continuous transition between the Rezi Dolomite and the Kössen Formation. The lithological change from the carbonate-dominated to the clay-dominated deposits likely reflects a significant climatic change at the end of Norian. Increased influx of terrestrial clay and organic matter can be related to enhanced seasonality and humidity which resulted in increased erosion on the continental hinterland (Bonis et al. 2010; Haas et al. 2012).

\section{Conclusions}

1. In the area of the Keszthely Mts., the pervasive dolomitization of the Norian carbonate sediments was the result of near-surface early diagenetic processes that were controlled mainly by the paleogeographic setting, the climatic conditions, and the structural evolution of the region.

2. In the latest Carnian a widely extended carbonate platform system came into being in the area of the TRU that was a sector of the passive margin of the western Neotethys Ocean. From the latest Carnian to Middle Norian under semi-arid climatic conditions huge amount of dolomites were formed in the peritidal to shallow subtidal internal parts of the carbonate platform (Fôdolomit Formation). The density-driven flux of seawater derived mesohaline fluids may have been the dominant mechanism of the near-surface early diagenetic pervasive dolomitization.

3. In the late Middle Norian incipient rifting of the Alpine Tethys led to an extensional structural regime in the south-western continent-ward part of the area of the TRU, and onset of the formation of a basin system (Kös- 
sen Basin) in the background of the remnant part of the Dachstein carbonate platform. In the study area the lack of inter- and supratidal facies in the "Keszthely-type dolomite" points to increasing water depth, and therefore, it can be interpreted as the indicator of the incipient stage of the basin evolution. This probably manifested itself by a change in the direction of the reflux, turning towards the newly formed back-platform basin. Coevally, remarkable changes took place in the climate; the permanent semi-arid regime was followed by alternating semi-arid and semi-humid periods. However, reflux dolomitization of the shallow subtidal carbonate succession may have continued during the drier periods. The synsediment fracturing of the semi-consolidated sediments may have promoted the flux of the dolomitizing fluid.

4. In the Late Norian, during the advanced phase of the development of the Kössen Basin predominantly platform-derived carbonate sediments were accumulated in the internal part of the fault-bounded semi-restricted sub-basins, whereas talus breccias and debrites were deposited near the basin-bounded faults. In the case of the lower and upper members of the Rezi Dolomite Formation the early diagenetic dolomitization may have taken place in shallow burial setting. Seawater, probably of slightly enhanced salinity, was the dolomitizing fluid, although the contribution of organogenic dolomitization cannot be excluded either. The extensional structural regime may have promoted the flux of seawater in the upper semi-consolidated part of the sediment column.

5. The finely to medium crystalline dolomite cement observed in the fenestral and biomouldic pores and synsedimentary fractures may have formed contemporaneously with the pervasive replacement dolomitization of the precursor carbonate sediments and the occasionally occurring pore-lining meteoric calcite cement. The medium to very coarse crystalline dolomite cement commonly occurs in the central part of wider fractures and also appears as lining in larger secondary pores. This cement phase was formed in deeper burial setting during the post-Triassic extensional structural regimes prevailed in the region from the Early Jurassic to the Early Cretaceous.

Supplementary Information The online version contains supplementary material available at https://doi.org/10.1007/s00531-021-02113-w.

Acknowledgements The research was supported by the European Union and the State of Hungary, co-financed by the European Regional Development Fund in the project of GINOP-2.3.2-15-2016-00009 'ICER', furthermore, by the Hungarian Scientific Research Fund (OTKA 124313). The authors are indebted to Zsanett Szilágyi for her technical contributions. The authors thank the reviewers Prof. Patrick
Meister and Prof. Jozef Michalik for contributing many valuable comments, which improved the manuscript considerably.

Funding Open access funding provided by Eötvös Loránd University.

Open Access This article is licensed under a Creative Commons Attribution 4.0 International License, which permits use, sharing, adaptation, distribution and reproduction in any medium or format, as long as you give appropriate credit to the original author(s) and the source, provide a link to the Creative Commons licence, and indicate if changes were made. The images or other third party material in this article are included in the article's Creative Commons licence, unless indicated otherwise in a credit line to the material. If material is not included in the article's Creative Commons licence and your intended use is not permitted by statutory regulation or exceeds the permitted use, you will need to obtain permission directly from the copyright holder. To view a copy of this licence, visit http://creativecommons.org/licenses/by/4.0/.

\section{References}

Berra F, Jadoul F, Anelli A (2010) Environmental controll on the end of the Dolomia Principale/Hauptdolomit depositional system in the central Alps: coupling sea-level and climatic changes. Palaeogeogr Palaeoclimatol Palaeoecol 290:138-150

Berra F, Azmy K, Della Porta G (2020) Stable-isotope and fluid inclusion constraints on the timing of diagenetic events in the dolomitized Dolomia Principale inner platform (Norian, Southern Alps of Italy). Mar Pet Geol 121:104615

Bonis NR, Ruhl M, Kürschner WM (2010) Climate change driven black shale deposition during the end-Triassic in the western Tethys. Palaeogeogr Palaeoclimatol Palaeoecol 290:151-159

Budai T, Koloszár L (1987) A Keszthelyi-hegység nóri-rhaeti képződményeinek rétegtani vizsgálata (Stratigraphic investigation of the Norian-Rhaetian formations in the Keszthely Mountains). Földtani Közlöny 117:121-130

Budai T, Kovács S (1986) Contributions to the stratigraphy of the Rezi Dolomite Formation (Metapolygnathus slovakensis, Conodonta, Upper Triassic) from the Keszthely Mts (W Hungary). Annu Rep Geol Inst Hungary 1984:175-191

Budai T, Csillag G, Dudko A, Koloszár L (1999a) Geological map of the Balaton Highland, 1:50 000. Geol Inst Hungary

Budai T, Császár G, Csillag G et al (1999b) Geology of the Balaton Highland. Explanation to the geological map of the Balaton Highland, 1:50 000. Occasional Papers of the Geol Inst Hungary, pp $197-257$

Csillag G, Budai T, Gyalog L, Koloszár L (1995) Contribution to the upper Triassic geology of the Keszthely Mountains (Transdanubian Range), western Hungary. Acta Geol Hung 38:111-129

Csontos L, Vörös A (2004) Mesozoic plate tectonic reconstruction of the Carpathian region. Palaeogeogr Palaeoclimatol Palaeoecol 210:1-56

Dickson JAD (1966) Carbonate identification and genesis as revealed by staining. J Sediment Res 36:491-505

Donofrio DA, Brandner R, Poleschinski W (2003) Conodonten der Seefeld-Formation: Ein Beitrag zur Bio-und Lithostratigraphie der Hauptdolomit-Plattform (Obertrias, Westliche Nördliche Kalkalpen, Tirol). Geol Mitteilungen Innsbruck 26:91-107

Du Y, Karádi V, Roghi G, Ponton M, Cozzi A, Rigo M (2021) Revision of the Conodont Mockina slovakensis and its paleogeographic implications for the Upper Triassic intraplatform basins of the Alps. J Earth Sci 32:657-666 
Fischer AG (1964) The Lofer cyclothem of the Alpine Triassic. In: Symposium on cyclic sedimentation. Kans Geol Surv Bull 169, pp 107-149

Fodor L, Koroknai B, Balogh K et al (2003) Nappe position of the Transdanubian Range Unit (Bakony) based on new structural and geochronological data from NE Slovenia). Bull Hung Geol Assoc 133:535-546

Fodor L, Uhrin A, Palotás K et al (2013) Geological and structural model of the Mura-Zala Basin and its rims as a basis for hydrogeological analysis. Annu Rep Geol Inst Hungary 2011:47-91

Folk RL (1962) Spectral subdivision of limestone types. In: Ham WE (ed) Classification of carbonate rocks-a symposium, vol 1. pp $62-84$

Frisch W, Kuhlemann J, Dunkl I, Brügel A (1998) Palinspastic reconstruction and topographic evolution of the Eastern Alps during late Tertiary extrusion. Tectonophysics 297:1-15

Gawlick HJ (2000) Paläogeographie der Ober-Trias Karbonatplatform in den Nördlichen Kalkalpen. Exkursionfürer Sediment 2000. Mitt Ges Geol Bergbaustud Österr 44:45-95

Gregg JM, Bish DL, Kaczmarek SE, Machel HG (2015) Mineralogy, nucleation and growth of dolomite in the laboratory and sedimentary environment: a review. Sedimentology 62:1749-1769

Haas J (1991) A basic model for Lofer cycles. In: Einsele G, Ricken W, Seilacher A (eds) Cycles and events in stratigraphy. SpringerVerlag, Berlin, Heidelberg, pp 722-732

Haas J (1993) Formation and evolution of the Kössen Basin in the Transdanubian range. Bull Hung Geol Soc 123:9-54

Haas J (2002) Origin and evolution of Late Triassic backplatform and intraplatform basins in the Transdanubian range, Hungary. Geol Carpathica 53:159-178

Haas J (2012) Geology of Hungary. Springer, London, p 244

Haas J, Budai T (1995) Upper Permian-Triassic facies zones in the Transdanubian Range. Riv Ital Di Paleontol e Stratigr 101:249-266

Haas J, Budai T (2004) Dunántúli-középhegységi egység. In: Magyarország geológiája. Triász (Geology of Hungary. Triassic). ELTE Eötvös Kiadó, Budapest. pp 25-124

Haas J, Jocháné-Edelényi E, Gidai L et al (1985) Geology of the Sümeg Area. Geol Hungar Ser Geol 20:353

Haas J, Kovács S, Krystyn L, Lein R (1995) Significance of Late Permian-Triassic facies zones in terrane reconstructions in the Alpine-North Pannonian domain. Tectonophysics 242:19-40

Haas J, Budai T, Csontos L et al (2010) Pre-Cenozoic geological map of Hungary. Geol Inst Hungary, Budapest

Haas J, Budai T, Raucsik B (2012) Climatic controls on sedimentary environments in the Triassic of the Transdanubian Range (Western Hungary). Palaeogeogr Palaeoclimatol Palaeoecol 353:31-44

Haas J, Budai T, Csontos L et al (2014a) Geology of the Pre-Cenonozoic basement of Hungary. Geological and Geophysical Institute of Hungary, Budapest, $\mathrm{p} 71$

Haas J, Budai T, Győri O, Kele S (2014b) Multiphase partial and selective dolomitization of Carnian reef limestone (Transdanubian Range, Hungary). Sedimentology 61:836-859

Haas J, Lukoczki G, Budai T, Demény A (2015) Genesis of upper Triassic peritidal dolomites in the Transdanubian Range, Hungary. Facies 61:8

Haas J, Hips K, Budai T et al (2017) Processes and controlling factors of polygenetic dolomite formation in the Transdanubian Range, Hungary: a synopsis. Int J Earth Sci 106:991-1021

Haas J, Jovanović D, Görög Á et al (2019) Upper Triassic-Middle Jurassic resedimented toe-of-slope and hemipelagic basin deposits in the Dinaridic Ophiolite Belt, Zlatar Mountain, SW Serbia. Facies 65:1-29

Hedges JI, Stern JH (1984) Carbon and nitrogen determinations of carbonate-containing solids. Limnol Oceanogr 29:657-663
Héja G, Kövér S, Csillag G et al (2018) Evidences for pre-orogenic passive-margin extension in a Cretaceous fold-and-thrust belt on the basis of combined seismic and field data (western Transdanubian Range, Hungary). Int J Earth Sci 107:2955-2973

Hetényi M, Brukner-Wein A, Sajgó C et al (2002) Variations in organic geochemistry and lithology of a carbonate sequence deposited in a backplatform basin (Triassic, Hungary). Org Geochem 33:1571-1591

Horváth F, Cloething S (1996) Stress-induced late-stage subsidence anomalies in the Pannonian basin. Tectonophysics 266:287-300

Iannace A, Frisia S (1994) Changing dolomitization styles from Norian to Rhaetian in the southern Tethys realm. In: Purser B, Tucker M, Zenger D (eds) Dolomites: a volume in honour of Dolomieu. International Association of Sedimentologists Special Publication, pp 75-89

Jadoul F, Masetti D, Cirilli S, et al (1994) Norian-Rhaetian stratigraphy and paeogeographic evolution of the Lombardy Basin (Bergamasc Alps). In: 15th IAS regional meeting, Ischia-Italy, Field Guide B1, p 38

Jadoul F, Galli MT, Berra F, et al (2004) The Late Triassic-Early Jurassic of the Lombardy Basin: stratigraphy, palaeogeography and palaeontology. In: 32nd international geological congress, Florence, Italy. Field trip guide book-P68. p 36

Jones GD, Xiao Y (2005) Dolomitization, anhydrite cementation, and porosity evolution in a reflux system: insights from reactive transport models. Am Assoc Pet Geol Bull 89:577-601

Karlik M, Fekete J, Mindrescu M et al (2018) Natural and anthropogenic changes in a lake-forest system in Bukovina (Romania) since $1340 \mathrm{AD}$ documented by sedimentary organic geochemistry (C, N and n-alkanes). Quat Int 493:166-175

Korte C, Kozur H, Bruckschen P, Veizer J (2003) Strontium isotope evolution of Late Permian and Triassic seawater. Geochimica et Cosmochimica Acta 67/1:47-62

Korte C, Kozur HW, Veizer J (2005) $\delta^{13} \mathrm{C}$ and $\delta^{18} \mathrm{O}$ values of Triassic brachiopods and carbonate rocks as proxies for coeval seawater and palaeotemperature. Palaeogeogr Palaeoclimatol Palaeoecol 226:287-306

Kovács Z, Demangel I, Richoz S et al (2020) New constraints on the evolution of $87 \mathrm{Sr} / 86 \mathrm{Sr}$ of seawater during the Upper Triassic. Glob Planet Change 192:103255

Kustatscher E, Daxer C, Krainer K (2017) Plant fossils from the Norian Seefeld Formation (Late Triassic) of the Northern Calcareous Alps (Tyrol, Austria) and their environmental/palaeoclimatic consequences. Neues Jahrb Geol Paläontol Abhandlungen 28:347-363

Land LS (1998) Failure to precipitate dolomite at $25^{\circ} \mathrm{C}$ from dilute solution despite 1000 -fold oversaturation after 32 years. Aquatic Geochem 4:361-368

Machel HG (2004) Concepts and models of dolomitization: a critical reappraisal. In: Braithwaite C, Rizzi G, Darke G (eds) The geometry and petrogenesis of dolomite hydrocarbon reservoirs. Geological Society, Special Publications, London, pp 7-63

Magyar I, Geary DH, Müller P (1999) Paleogeographic evolution of the late miocene Lake Pannon in Central Europe. Palaeogeogr Palaeoclimatol Palaeoecol 147:151-167

Manche CJ, Kaczmarek SE (2019) Evaluating reflux dolomitization using a novel high-resolution record of dolomite stoichiometry: a case study from the Cretaceous of central Texas, USA. Geology 47:586-590

Mandl GW (2000) The Alpine sector of the Tethyan shelf-examples of Triassic to Jurassic sedimentation and deformation from the Northern Calcareous Alps. Mitt Österreich Geol Gesellsch 92:61-77

Mazzullo SJ (2000) Organogenic dolomitization in peritidal to deepsea sediments. J Sediment Res 70:10-23 
McKenzie JA (1991) The dolomite problem: an outstanding controversy. In: Müller DW, McKenzie JA, Weissert H (eds) Controversies in modern geology. Academic Press, London, pp 37-54

Muttoni G, Mazza M, Mosher D et al (2014) A Middle-Late Triassic (Ladinian-Rhaetian) carbon and oxygen isotope record from the Tethyan Ocean. Palaeogeogr Palaeoclimatol Palaeoecol 399:246-259

Nebel O, Stammeier JA (2018) Strontium isotopes. In: White WM (ed) Encyclopedia of geochemistry. Encyclopedia of Earth Sciences series. Springer, Cham, pp 1379-1384

Purser BH, Tucker ME, Zenger DH (1994) Problems, progress and future research concerning dolomites and dolomitization. In: Purser BH, Tucker ME, Zenger DH (eds) Dolomites. International Association of Sedimentologists Special Publication, pp 3-20

Ratschbacher L, Frisch W, Linzer HG, Merle O (1991) Lateral extrusion in the Eastern Alps, part 2: structural analysis. Tectonics 10:257-271

Rieder M, Wegner W, Horschinegg M, Klackl S, Preto N, Breda A, Gier S, Klötzli U, Bernasconi SM, Arp G, Meister P (2019) Precipitation of dolomite from seawater on a Carnian coastal plain (Dolomites, northern Italy): evidence from carbonate petrographyand Sr isotopes. Solid Earth 10:1243-1267
Rosenbaum J, Sheppard SMF (1986) An isotopic study of siderites, dolomites and ankerites at high temperatures. Geochim Cosmochim Acta 50:1147-1150

Schmid SM, Aebli HR, Heller F, Zingg A (1989) The role of the Periadriatic line in the tectonic evolution of the Alps. In: Coward MP, Dietrich D, Park RG (eds) Alpine tectonics, vol 45. Geol Soc Spec Publ, London, pp 153-171

Sibley DF, Gregg JM (1987) Classification of dolomite rock textures. J Sediment Res 57:967-975

Spötl C, Vennemann TW (2003) Continuous-flow isotope ratio mass spectrometric analysis of carbonate minerals. Rapid Commun Mass Spectrom 17:1004-1006

Tari G, Horváth F (2010) Eo-Alpine evolution of the Transdanubian range in the nappe system of the Eastern Alps: revival of a 15 years old tectonic model. Bull Hung Geol Soc 140:483-510

Veizer J, Ala D, Azmy K, Bruckschen P et al (1999) ${ }^{87} \mathrm{Sr} /{ }^{86} \mathrm{Sr}, \delta^{13} \mathrm{C}$ and $\delta{ }^{18} \mathrm{O}$ evolution of Phanerozoic seawater. Chem Geol 161:59-88

Vető I, Hetényi M, Hámor-Vidó M et al (2000) Anaerobic degradation of organic matter controlled by productivity variation in a restricted Late Triassic basin. Org Geochem 31:439-452

Vörös A, Galácz A (1998) Jurassic palaeogeography of the Transdanubian Central Range (Hungary). Riv Ital Paleontol Stratigr 104:69-84 